University of Nebraska - Lincoln

DigitalCommons@University of Nebraska - Lincoln

USGS Staff -- Published Research

US Geological Survey

1999

\title{
Records of Millennial-Scale Climate Change From the Great Basin of the Western United States
}

Larry Benson

University of Colorado at Boulder, great.basin666@gmail.com

Follow this and additional works at: http://digitalcommons.unl.edu/usgsstaffpub

Benson, Larry, "Records of Millennial-Scale Climate Change From the Great Basin of the Western United States" (1999). USGS Staff -Published Research. 792.

http:// digitalcommons.unl.edu/usgsstaffpub/792

This Article is brought to you for free and open access by the US Geological Survey at DigitalCommons@University of Nebraska - Lincoln. It has been accepted for inclusion in USGS Staff -- Published Research by an authorized administrator of DigitalCommons@University of Nebraska - Lincoln. 


\title{
Records of Millennial-Scale Climate Change From the Great Basin of the Western United States
}

\author{
Larry Benson \\ U. S. Geological Survey, Boulder, CO
}

\begin{abstract}
High-resolution (decadal) records of climate change from the Owens, Mono, and Pyramid Lake basins of California and Nevada indicate that millennialscale oscillations in climate of the Great Basin occurred between 52.6 and 9.2 ${ }^{14} \mathrm{C}$ ka. Climate records from the Owens and Pyramid Lake basins indicate that most, but not all, glacier advances (stades) between 52.6 and $\sim 15.0{ }^{14} \mathrm{C}$ $\mathrm{ka}$ occurred during relatively dry times. During the last alpine glacial period $\left(\sim 60.0\right.$ to $\left.-14.0{ }^{14} \mathrm{C} \mathrm{ka}\right)$, stadial/interstadial oscillations were recorded in Owens and Pyramid Lake sediments by the negative response of phytoplankton productivity to the influx of glacially derived silicates. During glacier advances, rock flour diluted the TOC fraction of lake sediments and introduction of glacially derived suspended sediment also increased the turbidity of lake water, decreasing light penetration and photosynthetic production of organic carbon. It is not possible to correlate objectively peaks in the Owens and Pyramid Lake TOC records (interstades) with DansgaardOeschger interstades in the GISP2 ice-core $\delta^{18} \mathrm{O}$ record given uncertainties in age control and difference in the shapes of the OL90, PLC92 and GISP2 records. In the North Atlantic region, some climate records have clearly defined variability/cyclicity with periodicities of $10^{2}$ to $10^{3} \mathrm{yr}$; these records are correlatable over several thousand $\mathrm{km}$. In the Great Basin, climate proxies also have clearly defined variability with similar time constants, but the distance over which this variability can be correlated remains unknown. Globally, there may be minimal spatial scales (domains) within which climate varies coherently on centennial and millennial scales, but it is likely that the sizes of these domains vary with geographic setting and time. A more comprehensive understanding of the mechanisms of climate forcing and the physical linkages between climate forcing and system response is needed in order to predict the spatial scale(s) over which climate varies coherently.
\end{abstract}

\section{INTRODUCTION}

\section{Background}

Mechanisms of Global Climate Change at Millennial Time Scales Geophysical Monograph 112

Copyright 1999 by the American Geophysical Union
Studies of ice cores and marine sediments from the North Atlantic region indicate that millennial-scale climate 
variability was common during the last glacial cycle [Dansgaard et al., 1971; Johnsen et al., 1972; Dansgaard et al., 1984; Bond et al., 1992; Johnsen et al., 1992; Dansgaard et al., 1993; Grootes et al., 1993; Bond et al., 1993; Taylor et al., 1993; Mayewski et al., 1994; Bond and Lotti, 1995; Brook et al., 1996; Bond et al., 1997]. Millennial-scale oscillations in proxies of climate change have also been documented throughout other regions of the Northern Hemisphere [Allen and Anderson, 1993; Phillips et al., 1994; Porter and Zhisheng, 1995; Behl and Kennett, 1996; Benson et al., 1996a; Benson et al., 1997; Benson et al., 1998a; Hughen et al., 1996; Oviatt, 1997; Lund and Mix, 1998; and Lin et al., 1998]. Whether these oscillations were in phase, out of phase, or completely unrelated remains a fundamental question which, if answered, will lead to a more thorough understanding of the fundamental nature of the causes of global climate variability.

The Great Basin of the western United States provides an opportunity for obtaining high-resolution records of climate change from a region located outside the direct influence of the Atlantic Ocean. Lakes in the Great Basin have deep-water sedimentation rates as high as $2 \mathrm{~mm}$ yr $^{-1}$ [Benson et al., 1991], allowing recovery of less-thandecadal-scale records of climate variability. In addition, chemical and isotopic proxies of change in the size of lakes and glaciers have been developed and applied in highresolution studies of California's Owens and Mono Lakes [Benson et al., 1996a; Benson et al., 1997; Benson et al., 1998a,b]. Studies of Great Basin climate change, however, have limitations not encountered in the marine environment. The Great Basin is tectonically active [e.g., Huber, 1981; Beanland and Clark, 1994; Dixon et al., 1995], causing basin shapes to change and rivers to divert [Benson and Peterman, 1995]. These changes in hydrologic setting impose restrictions on interpretations of climate change based on chemical and physical indicators (proxies).

In the first part of this paper, I have attempted to present a concise summary of the results of high-resolution climate studies published by myself and my colleagues between 1996 and 1999. For details on laboratory procedures, age control, and the application of proxy indicators of climate, the reader is referred to the original publications [Benson et al., 1996a; Benson et al., 1997; Benson et al., 1998a,b]. In the second part of this paper, the lake based records of climate change are compared with climate records of the North Atlantic region and, in particular, with the timing of Heinrich events and stadialinterstadial oscillations documented in the Greenland GISP2 ice core.

\section{Hydrology and Climate of the Northern Great Basin}

Most of the precipitation falling in Sierra Nevada catchment areas that supply the Owens, Mono, and Pyramid lake basins is in the form of winter snow. The progression of maximum precipitation along the western flank of the Sierra Nevada is associated with southward movement of the mean position of the polar jet stream (PJS) [Horn and Bryson, 1960; Pyke, 1972; Riehl et al., 1954]. During summer, the westerlies weaken and Pacific storm tracks move north and the lake basins receive only minor amounts of moisture, originating primarily in the Gulf of California [Tang and Reiter, 1984; Adams and Comrie, 1997 and references therein]. Precipitation and streamflow in this region is uncorrelated with the $\mathrm{El}$ Nino/Southern Oscillation [Ropelewski and Halpert, 1986; Redmond and Koch, 1991].

During the late Pleistocene Tioga glaciation, Sierran ice fields extended from 36.4 to $39.7^{\circ} \mathrm{N}$ [Wahrhaftig and Birman, 1956] and valley glaciers formed between 36.2 and $40.2^{\circ} \mathrm{N}$ [Clark, 1995]. Pyramid, Owens, and Mono lakes occupied basins east of the Sierras between 36.2 and $41.8^{\circ} \mathrm{N}$ (Figure 1). During the past $50 \mathrm{ka}$, Pyramid Lake was one of several bodies of water that combined to form Lake Lahontan, a lake that covered an area of $23,000 \mathrm{~km}^{2}$ [Russell, 1885]. During the same period, Owens Lake intermittently overflowed [Gale, 1914] but Mono Lake remained hydrologically closed, falling $\sim 33 \mathrm{~m}$ short of its spill point [Lajoie, 1968].

\section{Objectives}

The ability to correlate climate oscillations across the Northem Hemisphere depends on several factors, including: (1) the ability of climate indicators (proxies) to distinguish between the fundamental elements of climate (temperature, precipitation, humidity, clouds, and wind), (2) age control and temporal resolution of climate records, (3) the spatial and temporal intensity of the climate signal, and (4) the rates of responses of climate proxies to climate forcing.

The objectives of this paper are to: (1) briefly discuss chemical parameters that have been used to indicate oscillations in alpine glaciation and hydrologic balances of Great Basin lakes, (2) review the strengths and limitations of methods of age control of lacustrine sediments, (3) present and discuss high-resolution records of climate change from the Owens, Pyramid, and Mono Lake basins, (4) discuss the correlation of these records with the GISP2 record of climate change, and (5) to examine the concept of spatial and temporal uniformity of climate change.

\section{LACUSTRINE PROXIES OF CLIMATE CHANGE}

\section{Proxies of Alpine Glaciation}

Alpine glaciers greatly increase the sediment load of streams that emanate from them [Hallet et al., 1996]. Sediment yields from glaciated basins generally depend on the extent of ice cover; however, other processes such as meltwater production, sliding speed and ice flux also affect yields [Hallet et al., 1996]. Nearly all indicators of alpine 
glaciation reflect the production of glacial rock flour and its input to a lake basin. Three proxies of glacier activity have recently been used in studies of Owens Lake sediments: magnetic susceptibility (MS), chemical composition of the carbonate-free clay-size fraction, and total organic carbon (TOC) [Benson et al., 1996a, 1998b; Bischoff et al., 1977a].

Magnetic susceptibility. Benson et al., [1996a] used variations in MS as a proxy for oscillations in the abundance of glacial rock flour. Assumptions implicit in this application are: (1) the fraction of bedrock-derived rock flour found in lake sediment is greater during times of glacial activity, and (2) that the magnetic moment/susceptibility of a sediment is proportional to the amount of glacial material in that sediment. During interglacial periods, magnetite concentrations can be diluted by autochthonous silicates and carbonates and by allochthonous detrital silicates [Bischoff et al., 1977a]. During interstades, magnetite concentrations can be diluted by organic carbon and amorphous silica derived from diatoms [Benson et al., 1998b].

Chemical composition of the carbonate-free clay-size fraction. Weathering of granite rocks in alpine and subalpine environments produces a grain size distribution similar to the parent material. Few rock fragments produced by weathering are in the clay-size fraction $(<2$ $\mu \mathrm{m})$; glacial abrasion of granitic bedrock, however, produces clay-size particles. Bischoff et al., [1997a] used this concept, showing that the rock flour component of lake sediment can be detected using elements that are relatively common to rock flour but rare in nonglacial materials (e.g., $\mathrm{Na}_{2} \mathrm{O}$ and $\mathrm{TiO}_{2}$ ).

Total organic carbon. Input of glacial rock flour to a lake dilutes the TOC fraction of lake sediment. The glacially-derived suspended sediment also increases the turbidity of lake water, decreasing photosynthetic production of organic carbon [Syvitski et al., 1990; Benson et al. 1996a]. Benson et al., [1996a] have suggested that seasonal ice cover and decreased water temperature further decrease productivity. Thus a number of physical and biological processes associated with glacier activity tend to reduce the amount of TOC deposited in lake sediment. In lakes in which diatoms are highly productive, their soft parts tend to increase the TOC content of lake sediment and their hard parts tend to increase the $\mathrm{SiO}_{2}$ content of lake sediment [Benson et al., 1998b].

\section{Proxies of Change in the Hydrologic Balance}

Oxygen-18 $\left({ }^{18} \mathrm{O}\right)$. The application of $\delta^{18} \mathrm{O}$ to the hydrologic balances of Great Basin lakes has been detailed in Benson [1994], Benson et al., [1996a,b] and references therein. The $\delta^{18} \mathrm{O}$ value of a steady-state hydrologically closed lake in the Great Basin will be $\sim 0 \%$. When

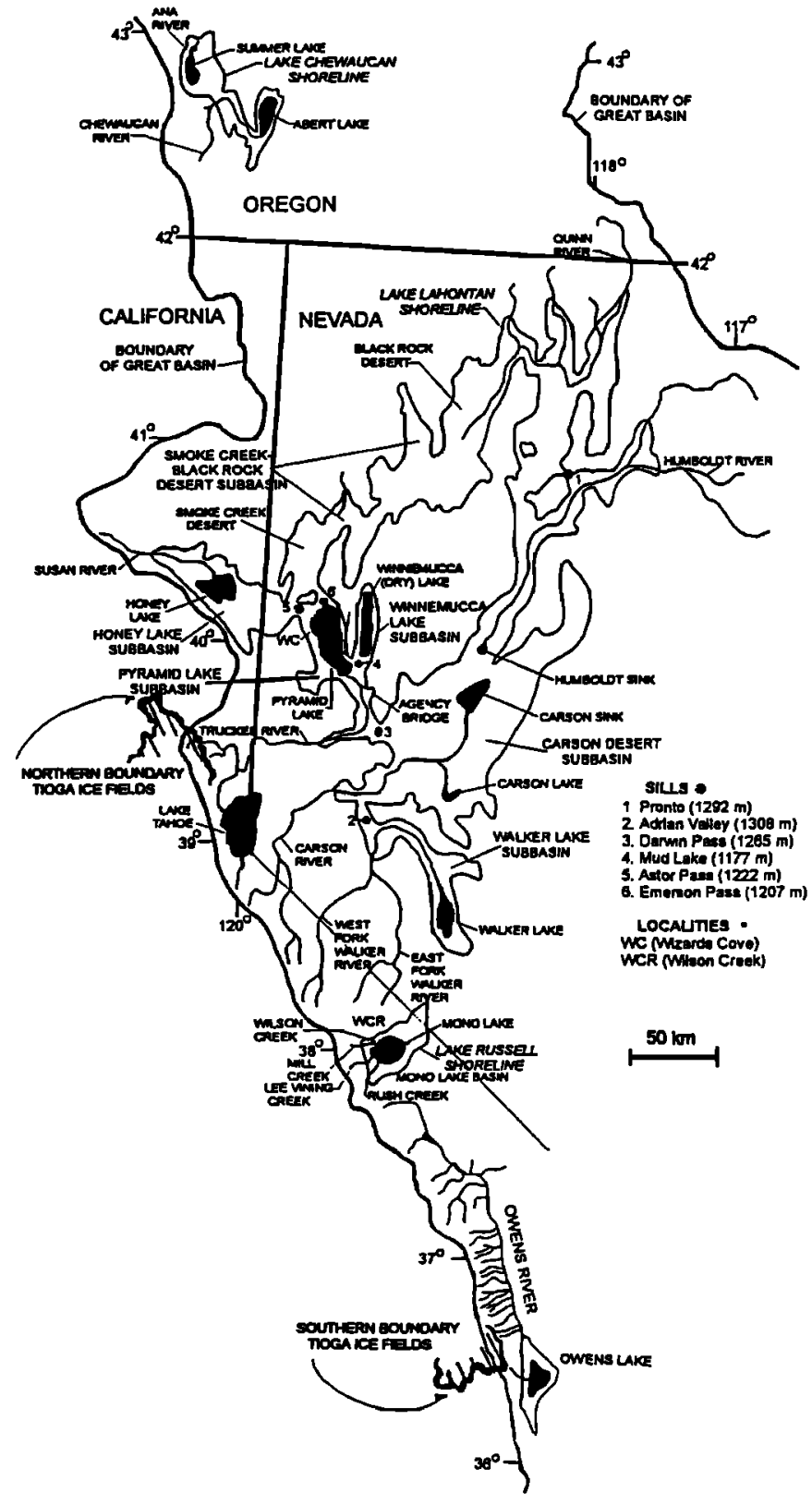

Figure 1. Map from Benson et al. [1998b] showing location of Pyramid Lake, Mono Lake and Owens Lake basins of California and Nevada. Latitudinal extent of Tioga glaciation (ice fields) is shown schematically [Wahrhaftig and Birman, 1956]. Highstand lake-surface areas at $\sim 13.0{ }^{14} \mathrm{C} \mathrm{ka}$ are also indicated.

input of isotopically light surface water exceeds the amount of water exported as evaporation, lake level rises and $\delta^{18} \mathrm{O}$ decreases and vice versa. The greater the rate of change in volume of a lake, the greater the excursion in $\delta^{18} O$. The $\delta^{18} \mathrm{O}$ value of lake water is path dependent; i.e., a specific lake volume cannot be assigned to a unique values of $\delta^{18} \mathrm{O}$. 
When a lake overflows, its $\delta^{18} \mathrm{O}$ value is proportional to the spill/discharge ratio. When that ratio approaches unity, the $\delta^{18} \mathrm{O}$ value of lake water approaches the $\delta^{18} \mathrm{O}$ value of streamflow discharge $(-13 \pm 2 \%$ for streams headed in the Sierra Nevada).

Total inorganic carbon (TIC). TIC can be used to approximate the hydrologic state of a paleolake if its signal is not confounded by glacier activity. The input of rock flour to a lake during alpine glacier advances can effectively mask the TIC signal by dilution of the carbonate fraction with silicate debris.

When hydrologically-closed Great Basin lakes receive dissolved solids from Sierran streams, nearly all dissolved $\mathrm{Ca}^{2+}$ precipitates as $\mathrm{CaCO}_{3}$ within a relatively short time (months to a few years). When a Great Basin lake overflows, precipitation of $\mathrm{CaCO}_{3}$ decreases and may even cease because the saturation state of lake water with respect to $\mathrm{CaCO}_{3}$ decreases as the lake becomes more dilute.

\section{Linkages of Glacial and Hydrologic Proxies to Elements of Climate Change}

None of the proxies previously discussed can be linked to a single element of climate change. Proxies of change in the hydrologic balance such as $\delta^{18} \mathrm{O}$ are functions of several elements of climate (water temperature, air temperature, wind speed, humidity) as well as the hydrologic state of the lake (closed or overflowing). Proxies of glacier oscillations such as MS and lake-sediment chemistry directly or indirectly reflect the production of glacial rock flour and its input to a lake basin, a complex process that is a function of multiple elements of climate that control glacier advances and retreats and the transport of glacial sediment to the lake basin. The fraction of TOC reaching a lake's sediment-water interface can be linked to glacier activity; however, biological processes which recycle carbon to the aqueous system are difficult to link to the elements of climate change. In addition, the TOC proxy is not sensitive to the upper limit of glacier extent; i.e., TOC can potentially achieve near zero values before rock-flour induced turbidity reaches a maximum. If lake overflow occurs during glaciation, clay-size material may leave the basin in the outflow, causing the intensity of glacial erosion to be underestimated.

\section{PROBLEMS OF AGE CONTROL}

Radiocarbon age controls for both lake and marine records are clouded by questions regarding the magnitudes of reservoir effects. A study by Broecker and Kaufman [1959] indicated modern reservoir effects of $\sim 150, \sim 600$, and $\sim 1700$ yr in Walker, Pyramid, and Mono Lakes. Radiocarbon ages of Great Basin lake sediments have usually been obtained on the TOC fraction. Only small amounts of detrital carbon reach Great Basin lakes [Galat $e t$ al., 1981; Benson et al., 1991]; therefore, the TOC based dates largely reflect the ${ }^{14} \mathrm{C} / \mathrm{C}$ ratio of algae which obtain their carbon from dissolved inorganic carbon (DIC) in a lake.

Little is known of the magnitudes of reservoir effects in Great Basin lakes during the past $50 \mathrm{ka}$. Thus, uncertainties in ${ }^{14} \mathrm{C}$-based age models of lacustrine and marine sediment cores are often of the same magnitude as the frequencies of the climate oscillations being compared, making it difficult to determine if the records are synchronous, asynchronous, or unrelated.

Studies of late Pleistocene lake sediments in the Mono Lake basin have historically relied on ${ }^{14} \mathrm{C}$ ages of subaerially exposed carbonates (tufas). Porous tufas, typical of the Mono Basin, do not usually remain closed systems with respect to carbon. Such carbonates acquire ${ }^{14} \mathrm{C}$ in the subaerial environment by a dissolution-reprecipitation process that occurs when low-pH rain comes in contact with the carbonate. In the Pyramid Lake basin, this process has been shown to decrease the apparent ${ }^{14} \mathrm{C}$ age of a porous carbonate by more than 1000 years [Thompson et al., 1986].

The use of paleomagnetic secular variation for correlation of lake records across the western United States has proven useful [Liddicoat and Coe, 1979; Negrini et al., 1984; Lund et al., 1988; and Liddicoat, 1992]. Lund [1996] in a comparison of nine Holocene PSV records from North America, has shown that distinctive field features in inclination and declination can often be traced more than $4000 \mathrm{~km}$ without significant change in pattern. The spatial extent of synchronous magnetic change remains a subject of debate and continued investigation [Thompson, 1983; Lund, 1993].

\section{METHODS}

Detailed coring procedures, sampling, and methods of chemical and physical analysis are described in Benson et al. [1996a, 1997, 1998a, 1998b] and Bischoff et al. [1997a]. In general, the $\delta^{18} O$ records discussed in this paper were created using $\delta^{18} \mathrm{O}$ values of the TIC fraction contained in bulk sediment samples. Sample reproducibility was $\leq 0.3 \%$. TIC and total carbon (TC) measurements were made with a commercial $\mathrm{CO}_{2}$ coulometer and TOC determined by difference. TIC and TOC values are generally reproducible to at least two significant figures.

\section{HIGH-RESOLUTION RECORDS OF CLIMATE CHANGE FROM THE GREAT BASIN}

\section{Owens Lake}

Core OL92 (150 to $15 \mathrm{ka})$. To place the highresolution Owens Lake data in perspective, mediumresolution $(\sim 1500 \mathrm{yr}) \delta^{18} \mathrm{O}$, TIC, and $\mathrm{Na}_{2} \mathrm{O}$ data records from core OL92 (Figure 2) for the period 150 to $15 \mathrm{ka}$ 


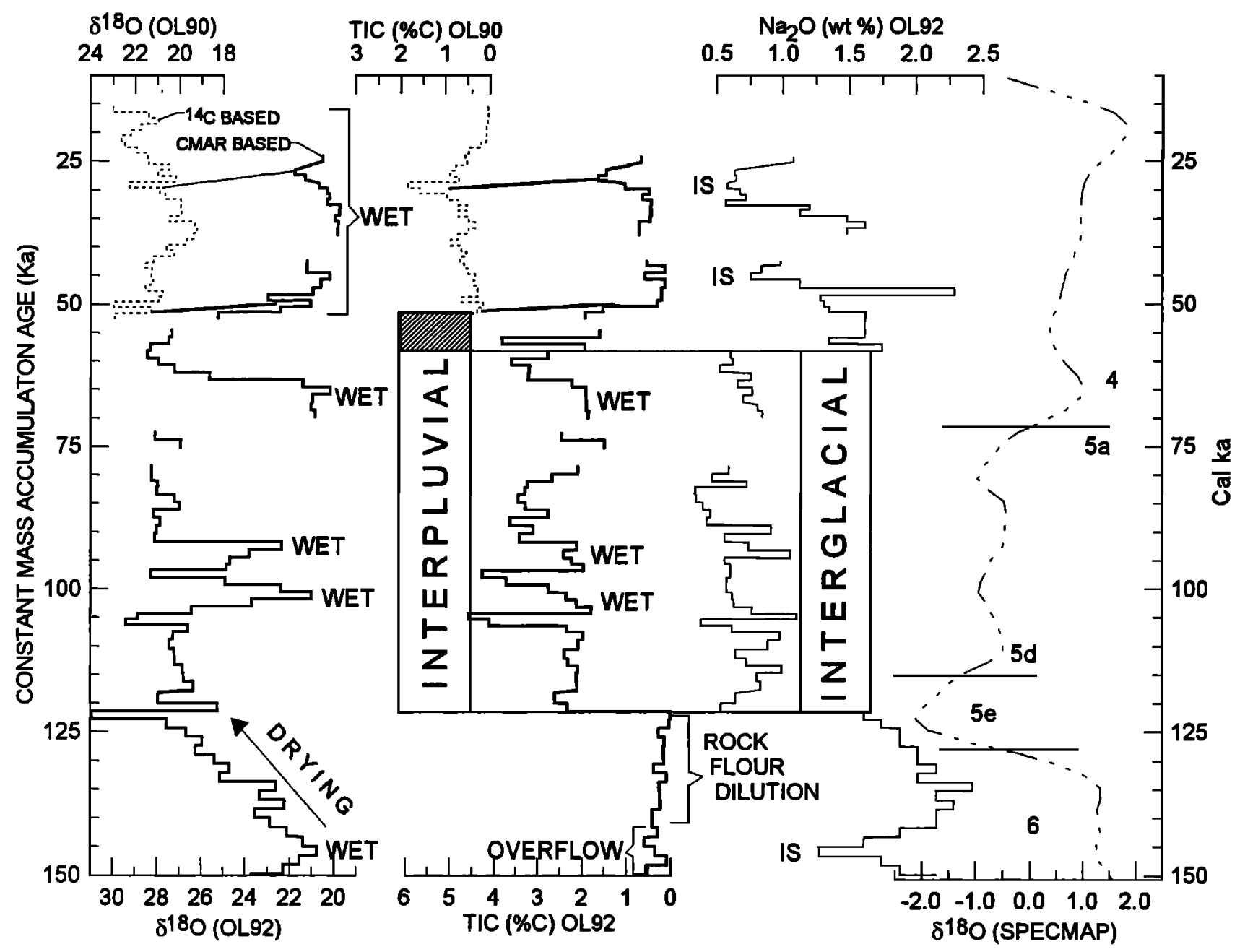

Figure 2. Oxygen-18 $\left(\delta^{18} \mathrm{O}\right)$, total inorganic carbon (TIC), and $\mathrm{Na}_{2} \mathrm{O}$ values of the clay-size fraction in sediment samples from Owens Lake cores OL90-1, OL90-2, and OL92. Dotted lines are plots of 1000-yr averages of data from OL90-1 and -2. Solid lines are plots of $\sim 1500$-yr channel samples from OL92. Age control for OL92 data (solid lines) is based on constant mass accumulation rate (CMAR) model. CMAR model for OL92 yields ages $\sim 2000$ yr younger than the ${ }^{14} \mathrm{C}$ based age model applied to OL90-1 and -2 at $50 \mathrm{ka}$ [Benson et al., 1996a]. The CMAR model was generated using a $3^{\text {rd }}$ degree polynomial fit to the data in Table 4 of Bischoff et al. [1997b]. The interpluvial period between 121 and $51 \mathrm{ka}$ is defined by generally low values of $\delta^{18} \mathrm{O}$ and TIC; the interglacial period is defined by low values of $\mathrm{Na}_{2} \mathrm{O}$ in the carbonate-free clay-size fraction. Note that wet-dry oscillations occurred during the alpine interglacial period and that glacier oscillations occurred during the last alpine glacial period (IS refers to interstades). Note also that interpluvial and alpine interglacial periods were not synchronous. The SPECMAP $\delta^{18} \mathrm{O}$ time series [Imbrie et al., 1984] with the boundary between isotope stages 4, 5a, 5d, 5e, and 6 [Shackleton, 1969] are shown for comparison. 


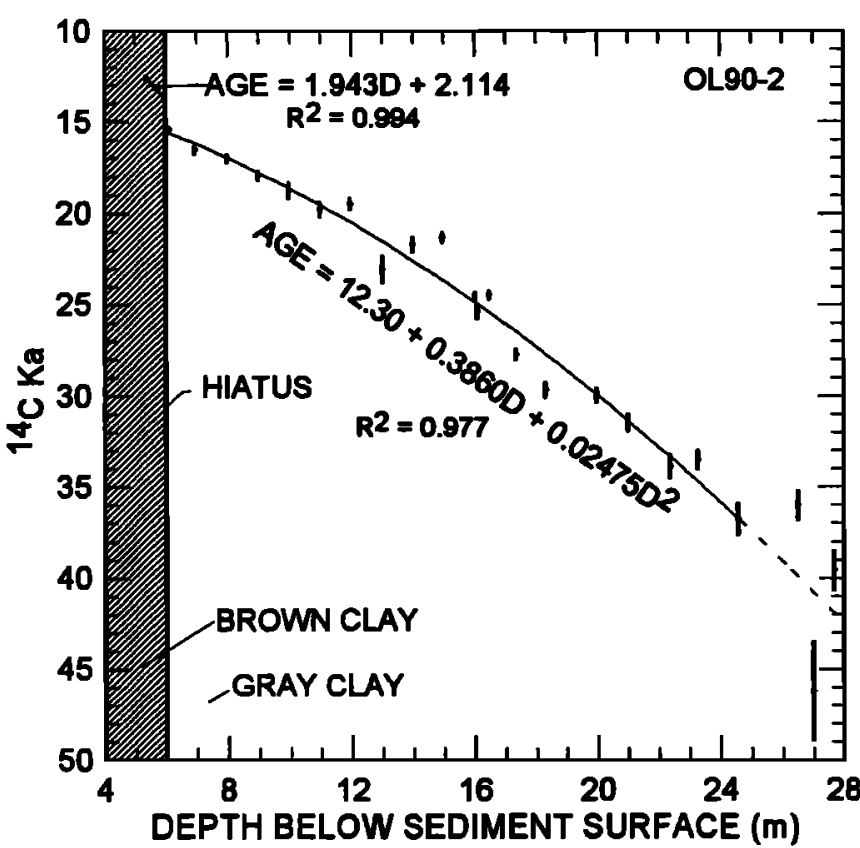

Figure 3. Radiocarbon $\left({ }^{14} \mathrm{C}\right)$ age-depth plot for OL90-2 from Benson et al. [1996a]. Prior to analysis all samples were pretreated with HCL to remove inorganic carbon. The oldest three samples were not used in the polynomial fit. ' $D$ ' in this and subsequent figures refers to depth. A sediment hiatus at $\sim 5.94 \mathrm{~m}$ is indicated by an offset in the ${ }^{14} \mathrm{C}$ ages and by an abrupt change in sediment color.

[Bischoff et al., 1997a; Menking et al., 1997] will be examined first. Age control for OL92 was provided by a constant mass accumulation rate (CMAR) model applied to sediments between the Bishop ash bed $(759 \mathrm{ka})$ boundary at $304 \mathrm{~m}$ and the top of the core [Bischoff et al., 1997b]. Because some sections near the top of OL92 were fluidized and contaminated during coring, 1000-yr averages of $\delta^{18} \mathrm{O}$ and TIC data from core OL90 were plotted (dotted line in Figure 2) beside the OL92 data.

The various proxies discussed above can be used to separate the 150,000 to $15,000 \mathrm{yr}$ period into intervals that are dominantly glacial/interglacial or pluvial/interpluvial (wet/dry). A case can be made that alpine glacial intervals were generally wet and interglacials were generally dry; however, none of the these intervals were climatically monotonic. The generally dry interpluvial was punctuated by three very wet periods of overflow, each of which lasted $\sim 5000 \mathrm{yr}$, and three interstades occurred during dominantly glacial intervals (Figure 2).

Pluvial/interpluvial and glacial/interglacial boundaries are not always coincident and the approach to those boundaries can be gradual or abrupt. The $\mathrm{Na}_{2} \mathrm{O}$ record indicates that the interstade centered on $145 \mathrm{ka}$ was followed by a strong glacial oscillation that peaked $\sim 135$ $\mathrm{ka}$; and at $122 \mathrm{ka}$, the climate shifted abruptly into an interglacial mode. The $\delta^{18} \mathrm{O}$ record, on the other hand, shows a gradual wet-to-dry transition between 145 and 122 ka. Overflow followed by input of glacial rock flour combined to suppress TIC values between 150 and $122 \mathrm{ka}$.

Cores OL90-1 and $-2\left(52.6\right.$ to $\left.12.5^{14} \mathrm{C} \mathrm{ka}\right)$. Sediment cores, OL90-1 (32.75 m), and OL90-2 (28.20 m), were obtained from the southem end of the Owens Lake basin in 1990 by Steve Lund of the University of Southern Califomia. Age control for OL90-2 was based on AMS ${ }^{14} \mathrm{C}$ determinations made on the TOC fraction of cored sediment. A hiatus in sedimentation at $5.94 \mathrm{~m}$ spans the $\leq 15.47$ to $13.66{ }^{14} \mathrm{C}$ ka interval. A $1^{\text {st }}$-degree polynomial was fit to the youngest three ages above the hiatus and a $2^{\text {nd }}$-degree polynomial was fit to all but the oldest three ages below the hiatus in order to provide age-depth models for this core (Figure 3).

Age control was extended to OL-90-1 by matching MS features common to OL90-1 and -2 (Figure 4). Having derived equivalent OL90-2 depths for OL90-1, the OL90-2 ${ }^{14} \mathrm{C}$ age-depth polynomial (Figure 5) was applied to OL901 .

The MS of Owens Lake sediments derives from detrital magnetite $\left(\mathrm{Fe}_{3} \mathrm{O}_{4}\right)$ and greigite $\left(\mathrm{Fe}_{3} \mathrm{~S}_{4}\right)$. Sequential measurement of the natural remanent magnetism (NRM) of

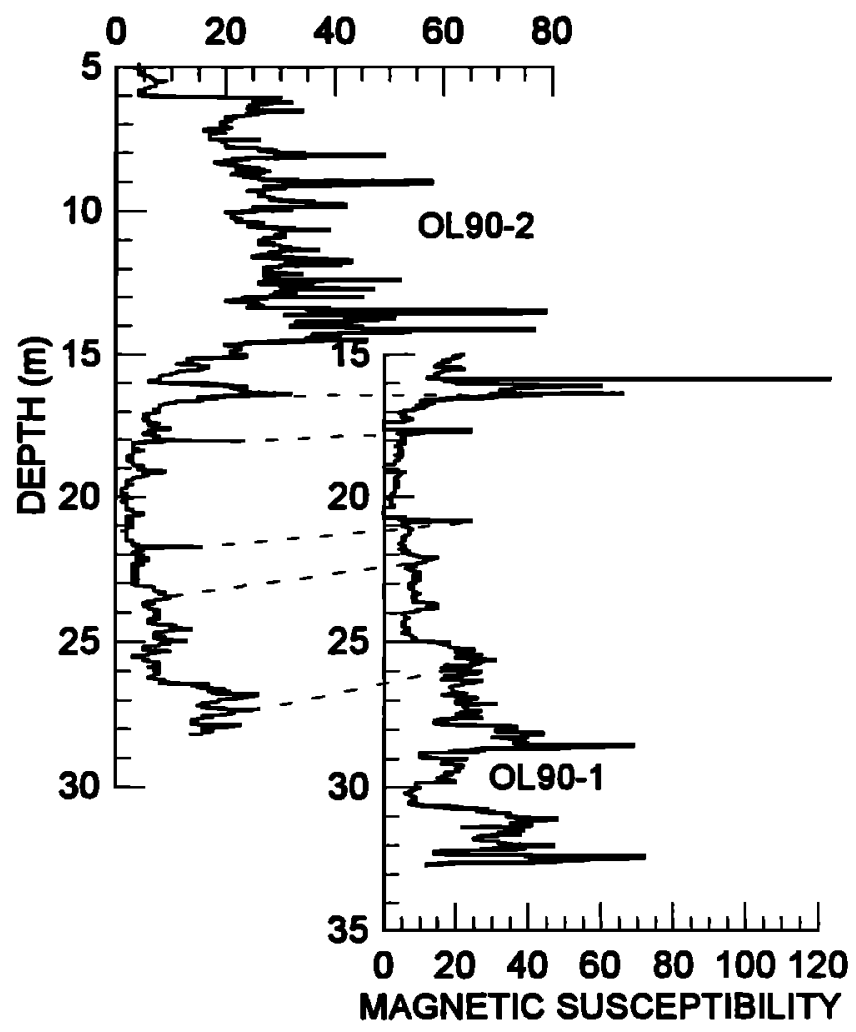

Figure 4. From Benson et al. [1998b]; Correlation of the magnetic susceptibility (MS) records between parts of OL90-1 and -2 . Not all 30 correlations used in Figure 5 are shown. 


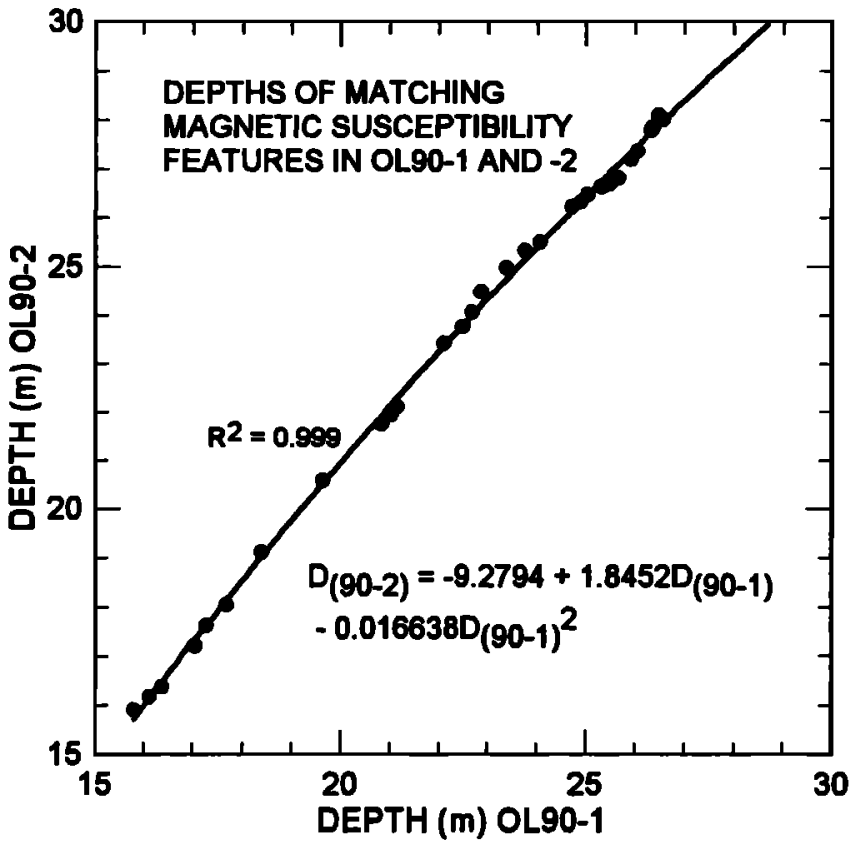

Figure 5. From Benson et al. [1998b]; $2^{\text {nd }}$-degree polynomial fit to MS features in OL90-1 and -2 .

samples from OL90-2, indicates that greigite is the most common magnetic mineral deposited between 23.2 and $15.5{ }^{14} \mathrm{C}$ ka. This conclusion is supported by thermomagnetic measurements of magnetic mineral blocking temperatures (unpublished data of S. Lund). Sequential measurements of NRM values of samples deposited between 13.66 and $12.5^{14} \mathrm{C} \mathrm{ka}$ and between 52.6 and $35.0{ }^{14} \mathrm{C}$ ka indicate that magnetite makes up the greater part of the magnetic mineral assemblage in these intervals (unpublished data of S. Lund).

As discussed in Benson et al. [1998b], high MS values in core OL90 distinguish two intervals $\left(52.6\right.$ to $40.0{ }^{14} \mathrm{C}$ $\mathrm{ka}$ and 25.5 to $15.47^{14} \mathrm{C}$ ka, Figure 6). Except for the low MS interval between 34.5 and $29.0^{14} \mathrm{C}$ ka, maxima in MS can be associated with minima in TOC. Each of the TOC minima and MS maxima are interpreted to result from a glacier advance (stade), during which detrital silicates (containing magnetic minerals) scoured from Sierran bedrock were dumped into Owens Lake, diluting the TOC fraction, reducing the photosynthetic production of organic carbon.

To further test for the presence of glacial oscillations, Benson et al. [1988b] Cs-exchanged the carbonate-free claysize fraction of 22 samples taken from peaks and troughs in the TOC record of OL90-1 and -2. These samples were then analyzed by inductively coupled plasma-atomic emission spectrometry (ICP-AES) and by inductively coupled plasma-mass spectrometry (ICP-MS). In general, all major rock forming elements excepting $\mathrm{SiO}_{2}$ were negatively correlated with TOC (see e.g., Figure 6). $\mathrm{TiO}_{2}$, a proxy for biotite, hornblende, and sphene, achieved its highest values during the Tioga glaciation when MS and TOC values were high and its lowest values at $\sim 30{ }^{14} \mathrm{C} \mathrm{ka}$ when MS and TOC values were low. In addition, the highest MS and lowest TOC values occur during the Tioga 2 and 3 glacier advances whose moraines mark the furthest advances of glaciers during the past $30{ }^{14} \mathrm{C} \mathrm{ka}$. These observations confirm that TOC and MS values are, at least, semiquantitative indicators of glacial extent.

Chemical analysis of the clay-size fraction indicated that 25 of 48 elements were negatively correlated $\left(R^{2}>0.5\right)$ with TOC, including $\mathrm{Cs}_{2} \mathrm{O}$, indicating that this oxide was associated with primary minerals such as feldspar and biotite [Hinkley, 1974] or biotite's alteration product vermiculite and not with secondary smectite clays [Bischoff et al., 1997a]. Eight clay-size samples left over from the ICP analyses were $\mathrm{Mg}$ exchanged, glycolated, and X-rayed. Their X-ray patterns showed that four of the samples did not contain detectable smectite and that mixed-layer clay was present in only minor amounts in the other four samples (Figure 6).

Optical inspection of the clay-size fraction of Owens Lake sediments indicated that much of the $\mathrm{SiO}_{2}$ determined in the ICP-AES analyses was associated with diatom fragments (amorphous $\mathrm{SiO}_{2}$ ). X-ray diffraction studies also revealed the presence of a broad peak centered at $\sim 22^{\circ} 2 \Theta$ in the high-SiO 2 samples, adding further support to the concept that diatom frustules were the source of much of the $\mathrm{SiO}_{2}$. These observations suggest that, during the last alpine glacial period, stadial/interstadial oscillations were recorded in Owens Lake sediments by the response of phytoplankton productivity to the influx of glacially derived silicates.

Millennial-scale oscillations in $\delta^{18} \mathrm{O}$ and TIC also occurred between 52.0 and $13.68{ }^{14} \mathrm{C}$ ka (Figure 7). Assuming that calcite precipitation occurred at $\sim 10^{\circ} \mathrm{C}$, the $\delta^{18} \mathrm{O}$ value of Owens Lake water between 52.6 and 13.68 ${ }^{14} \mathrm{C}$ ka was often $\leq-10 \%$, indicating numerous periods of overflow. Thus, the last alpine glacial period was generally a time of extreme wetness.

A series of pronounced maxima in $\delta^{18} \mathrm{O}$ between 52.6 and $-40.0{ }^{14} \mathrm{C}$ ka occur at about the same time as minima in TOC (Figures 7 and 8). The simplest explanation of the data is that the $\delta^{18} \mathrm{O}$ maxima represent closed-basin conditions (C-1...C-6). If oscillations in calcite $\delta^{18} \mathrm{O}$ values were caused by the effect of decreased water temperature on water-calcite isotopic fractionation, temperature would have had to oscillate between 13 and $23^{\circ} \mathrm{C}$ within a few hundred years. These ranges seem extreme given previous estimates of the temperature difference $\left(3\right.$ to $\left.7^{\circ} \mathrm{C}\right)$ between the glacial maximum and the Holocene time periods [Van Devender, 1973; Porter et al., 1983; Spaulding, 1983; Dohrenwend, 1984; Phillips et al., 1986; Benson and Klieforth, 1989; Stute et al., 1992]. 


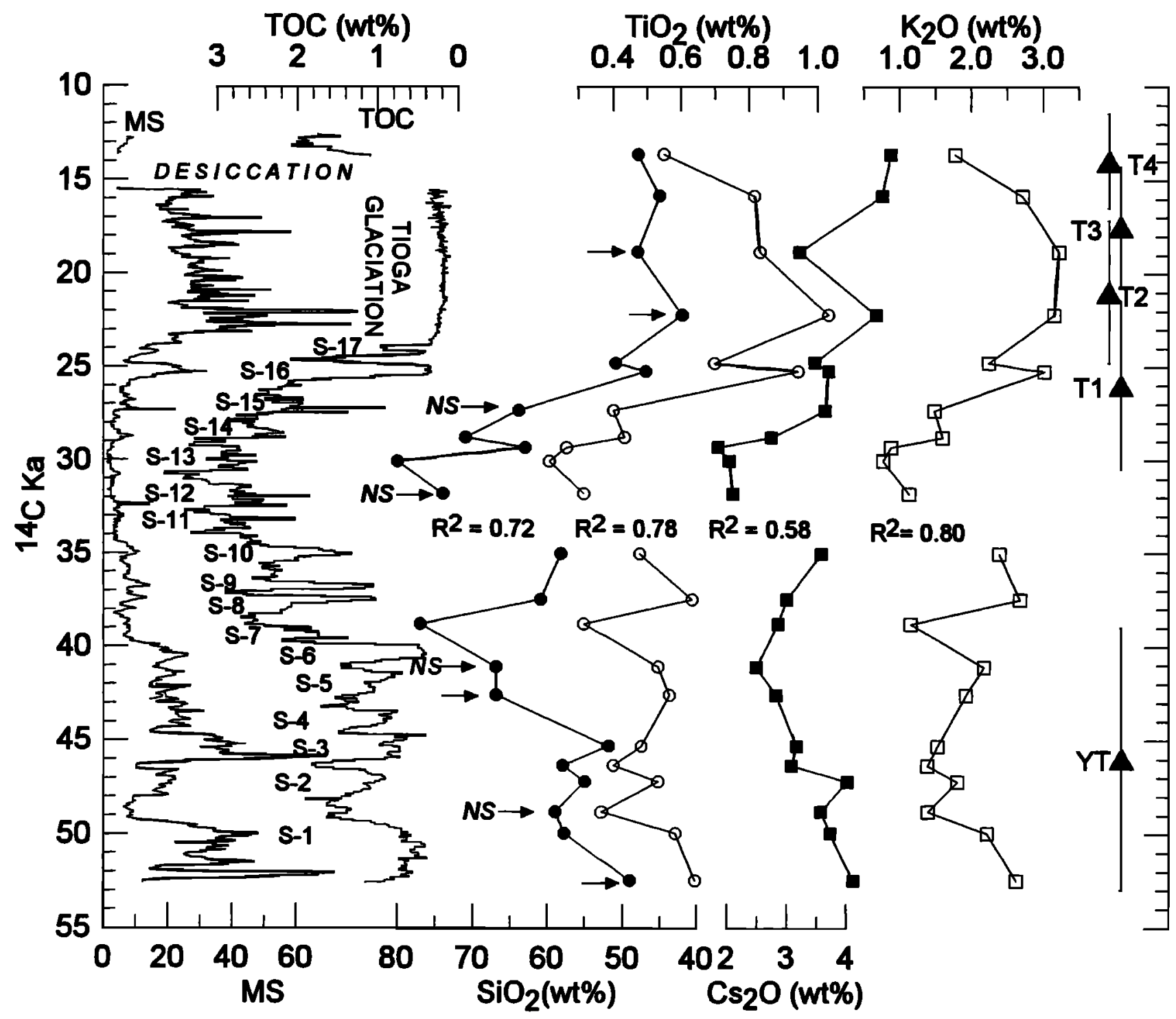

Figure 6. Plot of $\mathrm{MS}, \mathrm{TOC}, \mathrm{SiO}_{2}, \mathrm{TIO}_{2}, \mathrm{Cs}_{2} \mathrm{O}$, and $\mathrm{K}_{2} \mathrm{O}$ in the carbonate-free clay-size fraction of OL90. Note that $\mathrm{SiO}_{2}$ and TOC values are reversed relative to the other parameter values. 'T' and 'YT' indicate ${ }^{36} \mathrm{Cl}$ based ages of late Pleistocene Tioga and Younger Tahoe Sierran moraines [Phillips et al., 1996]. The emor bar associated with each moraine age includes maximum estimates of both systematic and random uncertainties [Phillips et al., 1997]. ' $S$ ' refers to alpine glacial stades. The $R^{2}$ value refers to correlation of the metal oxide with TOC. The arrows point to eight samples that were $\mathrm{Mg}$ saturated, glycolated and X-rayed. The X-ray diffraction patterns showed that smectite was absent from the four samples marked 'NS' and present in very small amounts in the other samples.

In addition, a 13 to $23^{\circ} \mathrm{C}$ change in condensation air temperature would have decreased the $\delta^{18} \mathrm{O}$ of precipitation by 7 to $13 \%$, more than offsetting any increase in calcite $\delta^{18} \mathrm{O}$ caused by decreased water temperatures.

Modem precipitation in the Lake Tahoe area of California has a volume-weighted $\delta^{18} \mathrm{O}$ value $-14.6 \%$ [Benson, 1994] and $\delta^{18} \mathrm{O}$ values of the West Fork of the Carson River, which drains the area immediately east of
Lake Tahoe, average $-14.3 \%$ (unpublished data of $\mathrm{L}$. Benson). Modern ground water from the Carson and Eagle Valleys located to the east and southeast of Lake Tahoe has $\delta^{18} \mathrm{O}$ values ranging from -12.7 to $-15.0 \%$ [Welch, 1994].

Data from the Honey Lake basin (Figure 1) that borders the eastern flank of the Sierra Nevada near Susanville, California, indicate that ground water with uncorrected ${ }^{14} \mathrm{C}$ 


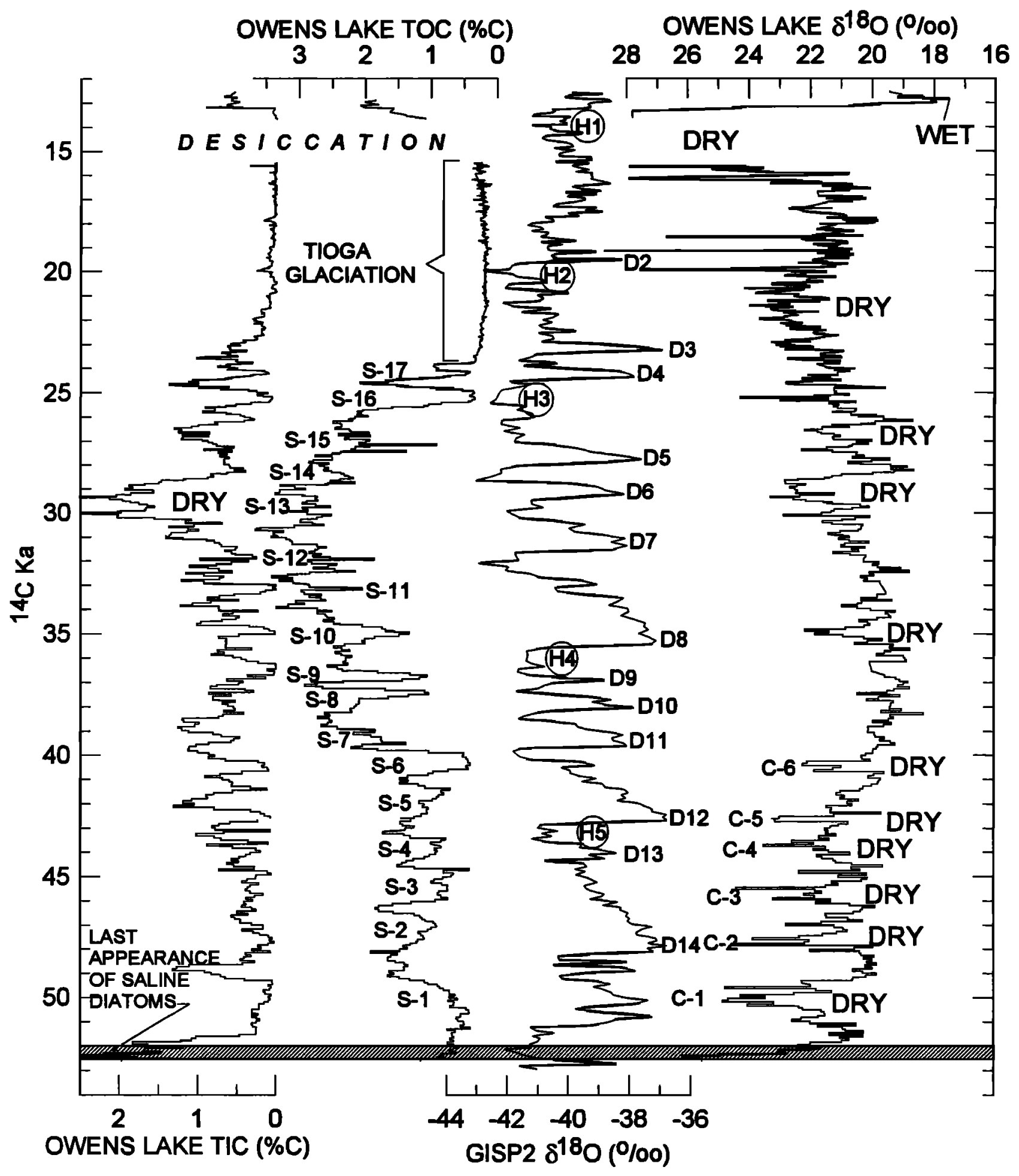

Figure 7. Owens Lake TIC, TOC and $\delta^{18} \mathrm{O}$ records compared with the $\delta^{18} \mathrm{O}$ record from GISP2 [Grootes et al., 1993]. The GISP2 data have been stretched to place Heinrich (H) events at 14.0 (H1), 20.0 (H2), 25.0 (H3), 36.0 (H4), and 43.0 (H5) ${ }^{14} \mathrm{C}$ ka The ${ }^{14} \mathrm{C}$ dates for Heinrich events $\mathrm{H} 2$ through $\mathrm{H} 5$ were obtained using the correlation made by Bond et al. [1993] between $\delta^{18} \mathrm{O}$ minima in North Atlantic and Greenland ice cores (GISP2). The GISP2 calendar age for each event was then transformed to a ${ }^{14} \mathrm{C}$ age using the data of Bard et al. [1993], [1996], [1990], and Kitagawa and van der Plicht [1998]. ' $S$ ' refers to Sierran stades, circled ' $H$ ' refers to North Atlantic Heinrich events, ' $D$ ' refers to Dansgaard-Oeschger stades, and ' $C$ ' refers to prominent times of hydrologic closure of Owens Lake before $35.0{ }^{14} \mathrm{C}$ ka 


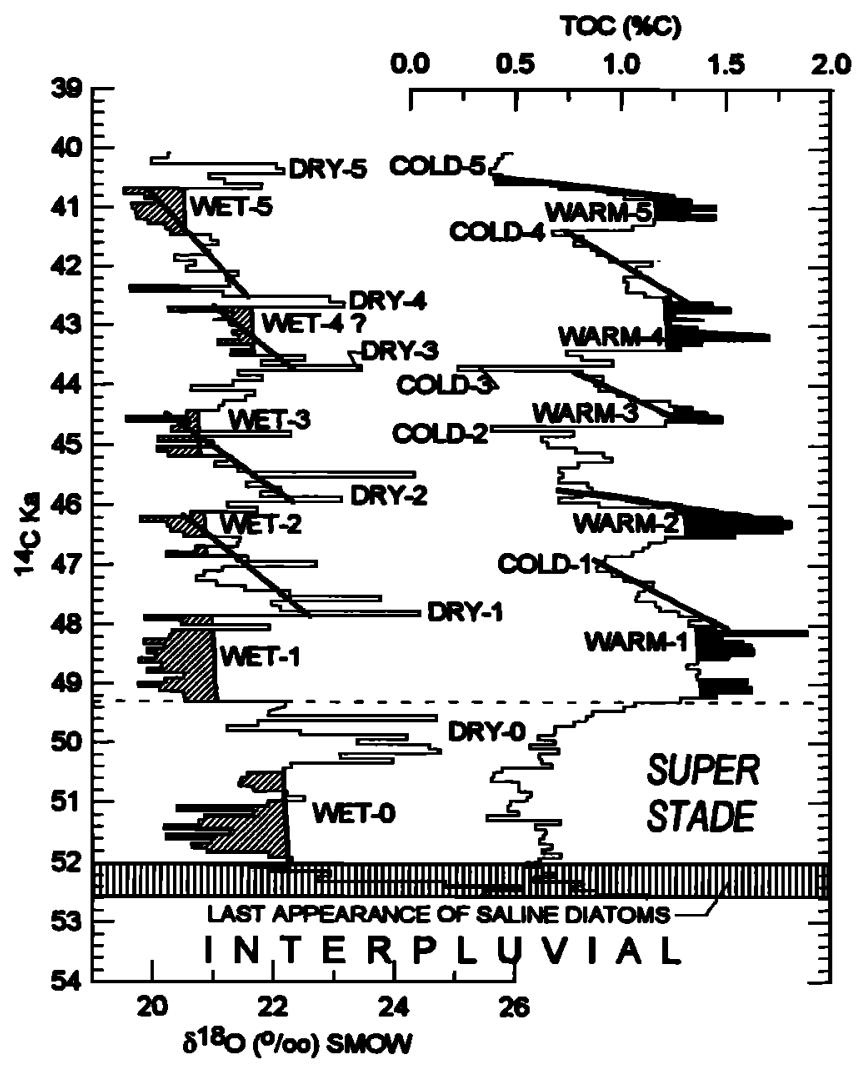

Figure 8. TOC and $\delta^{18} O$ values of sediments from OL90-1 and -2 between 52.6 and $40.0{ }^{14} \mathrm{C}$ ka Saline diatoms are gone from the core by $52.0{ }^{14} \mathrm{C} \mathrm{ka}$ indicating the transition to pluvial conditions (J. Bradbury personal communication). Relatively warm glacial interstades indicated by high TOC concentrations are denoted by the word 'WARM'. Each of the five interstades occurred when $\delta^{18} O$ values were low, indicating 'WET' overflowing conditions. Between 52.3 and $49.3{ }^{14} \mathrm{C} \mathrm{ka}$, a wet-dry oscillation occurred during an exceptionally long stade.

ages of 19.0 to $14.4{ }^{14} \mathrm{C}$ ka has $\delta^{18} \mathrm{O}$ values ranging from 14.1 to $-15.2 \%$ [Rose et al., 1997]. Ground water with an uncorrected ${ }^{14} \mathrm{C}$ age of $15.4 \pm 0.8 \mathrm{ka}$ from a drill hole located south of Walker Lake, Nevada (Figure 1), has $\delta^{18} \mathrm{O}$ values ranging from -15.4 to $-15.7 \%$ (unpublished data of L. Benson); and ground water from beneath the northern and eastern sides of the Owens Lake Playa with uncorrected ${ }^{14} \mathrm{C}$ ages of $28.7 \pm 0.9 \mathrm{ka}$ and $33.5 \pm 1.2 \mathrm{ka}$ has $\delta^{18} \mathrm{O}$ values of -16.8 and $-16.9 \%$ [Font, 1995]. These data suggest that late Pleistocene precipitation was only $\sim 2$ $\%$ more negative than modern-day precipitation, implying that condensation air temperatures were only a few degrees colder in the late Pleistocene than today. Therefore, air and water temperature changes were not sufficiently large to account for observed changes in $\delta^{18} \mathrm{O}$ between 52.6 and $40.0{ }^{14} \mathrm{C}$ ka further supporting the argument that alpine glacial stades were characterized by relatively dry climates during a very wet period.

Variations in $\delta^{18} \mathrm{O}$ and TOC between 48.0 and $40.6{ }^{14} \mathrm{C}$ $\mathrm{ka}$ are asymmetric and warm-cold and dry-wet transitions are offset (Figure 8). Some glacier advances (decreases in TOC) tend to take $\sim 1000 \mathrm{yr}$, whereas all glacier retreats (increases in TOC) take only a few hundred years.

The lowest values of $\delta^{18} \mathrm{O}$ occur between 40.0 and 32.0 ${ }^{14} \mathrm{C} \mathrm{ka}$ and at 28.2 and $26.2{ }^{14} \mathrm{C}$ ka (Figure 7). The 40.0 to $32.0{ }^{14} \mathrm{C}$ ka interval exhibits much less $\delta^{18} \mathrm{O}$ variability than the 52.6 to $-40.0^{14} \mathrm{C}$ ka interval, containing only one notable $\delta^{18} \mathrm{O}$ oscillation at $35.0^{14} \mathrm{C}$ ka. Between 26.0 and $\sim 15.5{ }^{14} \mathrm{C} \mathrm{ka}, \delta^{18} \mathrm{O}$ variability is generally small although a broad maxima in $\delta^{18} \mathrm{O}$ is centered at $\sim 21.5^{14} \mathrm{C} \mathrm{ka}$. The five very large ( $>26 \%$ ) values in $\delta^{18} O$ between 20.0 and $\sim 15.5{ }^{14} \mathrm{C}$ ka may represent rapid drops in lake level; but more probably, they indicate contamination of samples with carbonates derived from the Sierra or Inyo-White Mountains.

The hiatus in the sediment record between 15.47 and $13.68{ }^{14} \mathrm{C}$ ka represents a time of extreme aridity. TIC measurements, before and after extraction of soluble salts, demonstrate the presence of $-0.5 \%$ soluble inorganic carbon in the sediment immediately below the hiatus; and decrease in soluble TIC with depth indicates vertical diffusion of dissolved solids from a shallow saline lake (Figure 9). Sediments that bracket this hiatus in other cores (OL84B and OL97) have yielded dates of $\sim 14.8 \pm$ 0.10 and $13.38 \pm 0.07{ }^{12} \mathrm{C}$ ka [Benson et al., 1997] and $16.38 \pm 0.09$ and $13.31 \pm 0.06{ }^{14} \mathrm{C}$ ka (CAMS\# 41701 and 41702; unpublished data of $M$. Kashgarian and $L$. Benson). The difference in ages of sediment from immediately below the hiatus indicate that material was removed from the lake bed by water erosion (when the lake was very shallow) or by wind erosion (after the sediment was subaerially exposed). Dates on the lower surface, therefore, yield maximum estimates of the initiation of the dry period.

Owens Lake $\delta^{18} \mathrm{O}$ reached its lowest values at $13.0{ }^{14} \mathrm{C}$ ka (Figure 7), indicating a time of extreme overflow. If a water temperature of $15^{\circ} \mathrm{C}$ is assumed to exist at this time, the $\delta^{18} \mathrm{O}$ value of lake water was $-13 \%$, implying a overflow/discharge ratio that approached unity.

Most (14 of 17) stades were accompanied by decreases in TIC, indicating dilution with glacially derived silicates. This process neutralizes the ability of TIC to function as a proxy for change in the hydrologic balance for much of the OL90 record. An exception to this generalization occurs between 30.5 and $28.5{ }^{14} \mathrm{C}$ ka when TIC and $\delta^{18} \mathrm{O}$ values were both high, indicating aridity. Between 24.0 and 15.5 ${ }^{14} \mathrm{C} \mathrm{ka}$, transport of materials of glacial origin to Owens Lake was sufficient to almost completely mask the TIC fraction (Figure 7).

Core OL84B (13.4 to $\left.9.2{ }^{14} \mathrm{C} \mathrm{ka}\right)$. Samples from OL84B were used to obtain $\delta^{18} \mathrm{O}$, TIC, and TOC records 


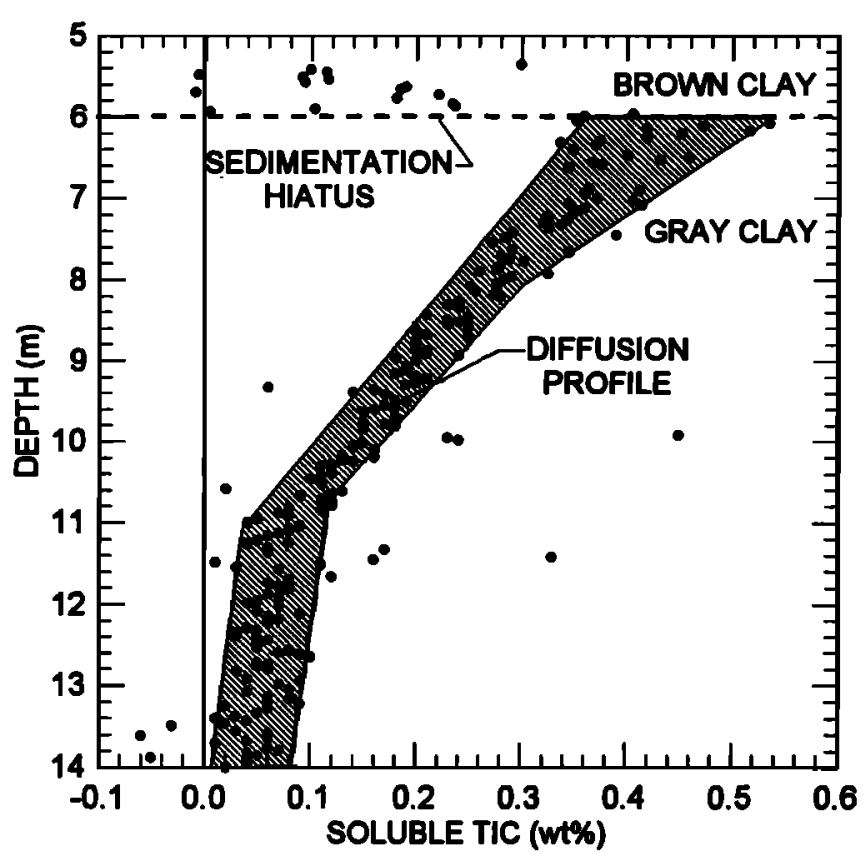

Figure 9. Weight \% soluble TIC as a function of depth in OL90-2. A hiatus in sedimentation occurs at $6.0 \mathrm{~m}$. Below that depth, the amount of soluble carbon decreases, indicating that a high-carbonate brine occupied Owens Lake basin prior to the desiccation of Owens Lake.

for the period 13.6 to $9.2{ }^{14} \mathrm{C}$ ka (Figure 10). Age control for OL84B is based on 11 AMS ${ }^{14} \mathrm{C}$ determinations made on the total organic carbon (TOC) fraction of cored sediment (Figure 11). The ${ }^{14} \mathrm{C}$ data indicate hiatuses in the sedimentary record at 2.25 and $9.20 \mathrm{~m} \mathrm{(6.1} \mathrm{to} 4.3$ and 14.8 to $13.38{ }^{14} \mathrm{C} \mathrm{ka}$ ). The 9.20 -m hiatus in OL84B is, therefore, equivalent to the hiatus at $5.94 \mathrm{~m}$ in OL90-2. Judging from the OL84B and OL90-2 records, the $\mathrm{W}_{1 \mathrm{a}}$ wet event appears to have begun later in OL84B, probably reflecting a 300-yr offset in the age models applied to the two cores.

In OL84B, the $\delta^{18} \mathrm{O}$ and TIC records (Figure 10) indicate a series of abrupt and extreme oscillations between 13.0 and $9.5{ }^{14} \mathrm{C} \mathrm{ka}$. TIC closely parallels variation in $\delta^{18} \mathrm{O}$ after $12.85{ }^{14} \mathrm{C} \mathrm{ka}$ This parallelism, and the magnitude of variability in $\delta^{18} \mathrm{O}(10 \%)$, suggest that $\delta^{18} \mathrm{O}$ maxima represent closed-basin conditions and $\delta^{18} \mathrm{O}$ minima represent times of overflow. Four dry $\left(D_{n}\right)$ intervals occur during this interval, including $D_{1}$ (the lateWisconsin desiccation) and $D_{4}$ which marks the beginning of the Holocene. If a water temperature of $25^{\circ} \mathrm{C}$ is assumed for the dry $\left(D_{n}\right)$ intervals, a calculation indicates that the $\delta^{18} O$ value of lake water was $0 \pm 1 \%$, a value consistent with hydrologically closed conditions.

In detail, abrupt increases in TIC in core OL84B tend to occur $\sim 1000$ yr prior to major increases in $\delta^{18} \mathrm{O}$, probably indicating the effect of residence time on the amount of $\mathrm{Ca}^{2+}$ and $\mathrm{CO}_{3}^{2-}$ dissolved in lake water. When the overflow/discharge ratio approached unity, little $\mathrm{CaCO}_{3}$ precipitated from lake water; but when overflow slowed, and the overflow/discharge ratio decreased, $\mathrm{CaCO}_{3}$ began to precipitate in quantity.

The TOC data for OL84B do not exhibit the oscillatory behavior documented in OL90-1 and -2. From 13.2 to 9.2 ${ }^{14} \mathrm{C} \mathrm{ka}$, TOC gradually increases with no indication of productivity decreases that signal glacier activity. This is consistent with the work of Clark and his colleagues [Clark et al., 1995; Clark, 1997; Clark and Gillespie, 1997] who demonstrated that all but the highest cirques in the Sierra Nevada were deglaciated by $13.1 \pm 0.07{ }^{14} \mathrm{C}$ ka and that the last Pleistocene Sierran glacier advance (Recess Peak) occurred between $12.2 \pm 0.06$ and $11.19 \pm 0.07{ }^{14} \mathrm{C}$ ka. Clark and Gillespie's [1997] reconstruction of glaciers along the crest of the Sierra Nevada indicated that during the Recess Peak advance, equilibrium-line altitudes (ELA) dropped by only $\sim 20 \%$ of the maximum late-Pleistocene

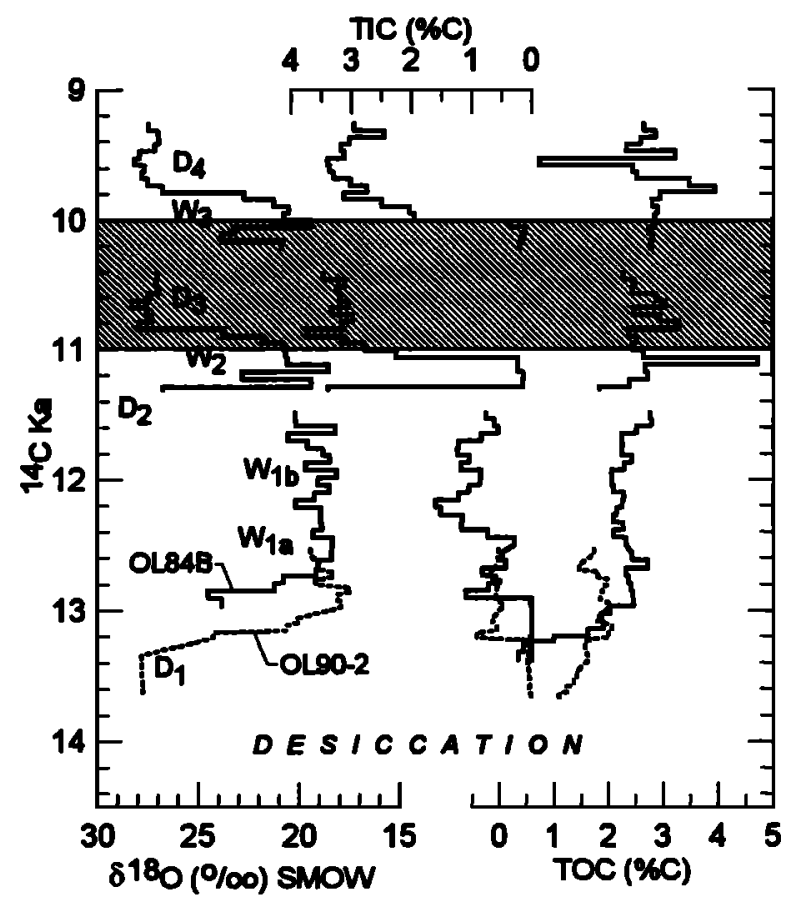

Figure 10. TIC, TOC, and $\delta^{18} \mathrm{O}$ values of sediments from OL84B between 13.6 and $9.2{ }^{14} \mathrm{C}$ ka (solid lines) plotted using age control of Figure 11. ' $D$ ' indicates $d r y$ and ' $W$ ' indicates wet periods. Dashed line indicates same data for OL90-2 subsequent to desiccation of Owens Lake. An abrupt oscillation in wetness occurred during the Younger Dryas chronozone (shaded rectangle). During wet-dry transitions, TIC increases before decreases in $\delta^{18} \mathrm{O}$. This may be due to the rapid response of carbonate precipitation during hydrologic closure [Benson et al., 1996a]. 


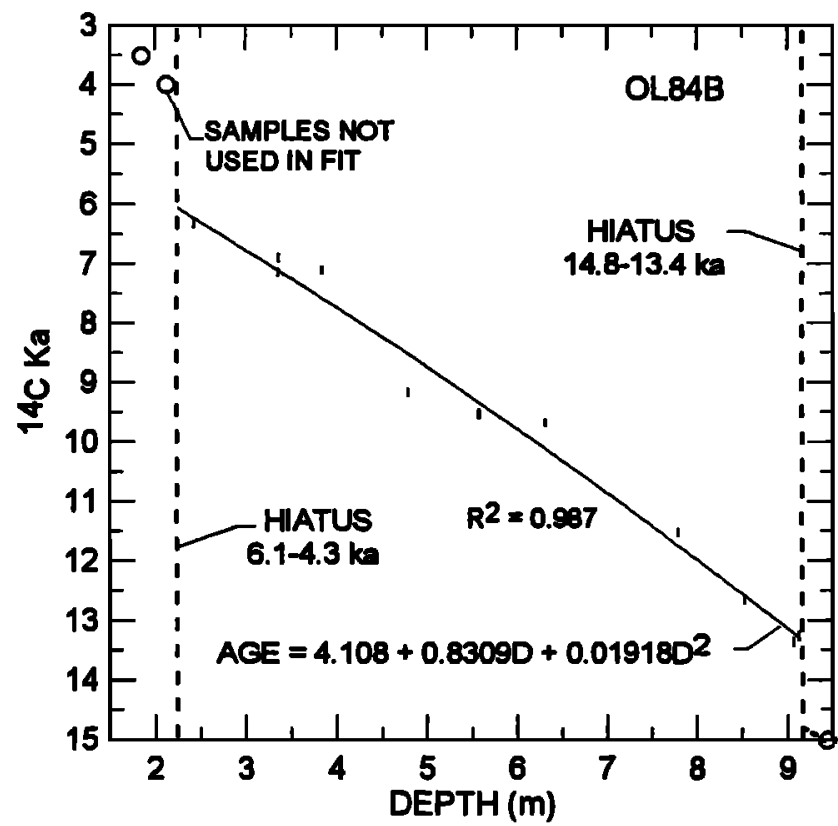

Figure 11. Radiocarbon age-depth plot for samples between 1.85 and $9.43 \mathrm{~m}$ in OL84B. The samples indicated by empty circles were not used in the $2^{\text {nd }}$-degree polynomial fit.

ELA change. The production of rock flour by this relatively small and perhaps brief advance appears too small to have affected the productivity of Owens Lake.

Between 13.7 and $\sim 13.2{ }^{14} \mathrm{C}$ ka (OL90-2 time scale), TIC and TOC values are low and $\delta^{18} \mathrm{O}$ values are high (Figure 10). TIC values of six samples in this interval are near zero and only two samples yielded sufficient $\mathrm{CaCO}_{3}$ for isotopic analysis. These data indicate that after the lateWisconsin desiccation of Owens Lake, climate became very wet and glacially derived detrital silicates were remobilized, diluting the TIC and TOC fractions in Owens Lake sediment. The high $\delta^{18} O$ values may represent contamination of the TIC fraction with pre-Wisconsin-age carbonates.

Solar Forcing of Wisconsin-age Sierran Glaciers in the Owens Lake Basin

Low-frequency changes in the size of Sierran glaciers appear related to summer solar insolation (Figure 12). The period of most extensive alpine glaciation, the Tioga, occurred between 24.0 and $\sim 15.0{ }^{94} \mathrm{C} \mathrm{ka}$, when summer insolation was very low. Glacier advances between $\mathbf{3 4 . 0}$ and $26.0{ }^{14} \mathrm{C}$ ka appear to have been blunted by high values of summer insolation when summer ablation rates increased relative to winter accumulation rates.
Comparison of Owens Lake Records With North Atlantic Climate Events

The Owens Lake MS and TOC records indicate that the Sierra Nevada experienced at least 17 stadial-interstadial oscillations between 52.0 and $24.0{ }^{14} \mathrm{C}$ ka (Figure 7). The work of Phillips et al. [1996] indicates that at least three moraines formed between 24.0 and $14.0{ }^{14} \mathrm{C}$ ka (Figure 6). Therefore, no less than 20 stadial-interstadial oscillations occurred between 52.0 and $14.0{ }^{14} \mathrm{C}$ ka. High-amplitude millennial-scale oscillations in ${ }^{18} \mathrm{O}$ occurred between 52.5 and 40.0 and between 15.0 and $9.5{ }^{14} \mathrm{C}$ ka (Figures 7, 8, and 10). In general, periods of greatest climatic (hydrologic) instability in the Owens basin were confined to periods of intermediate continental ice volume.

Comparison of OL90-1 and -2 TOC, TIC, and $8^{18} \mathrm{O}$ records with the GISP2 $\delta^{18} \mathrm{O}$ record indicates that the

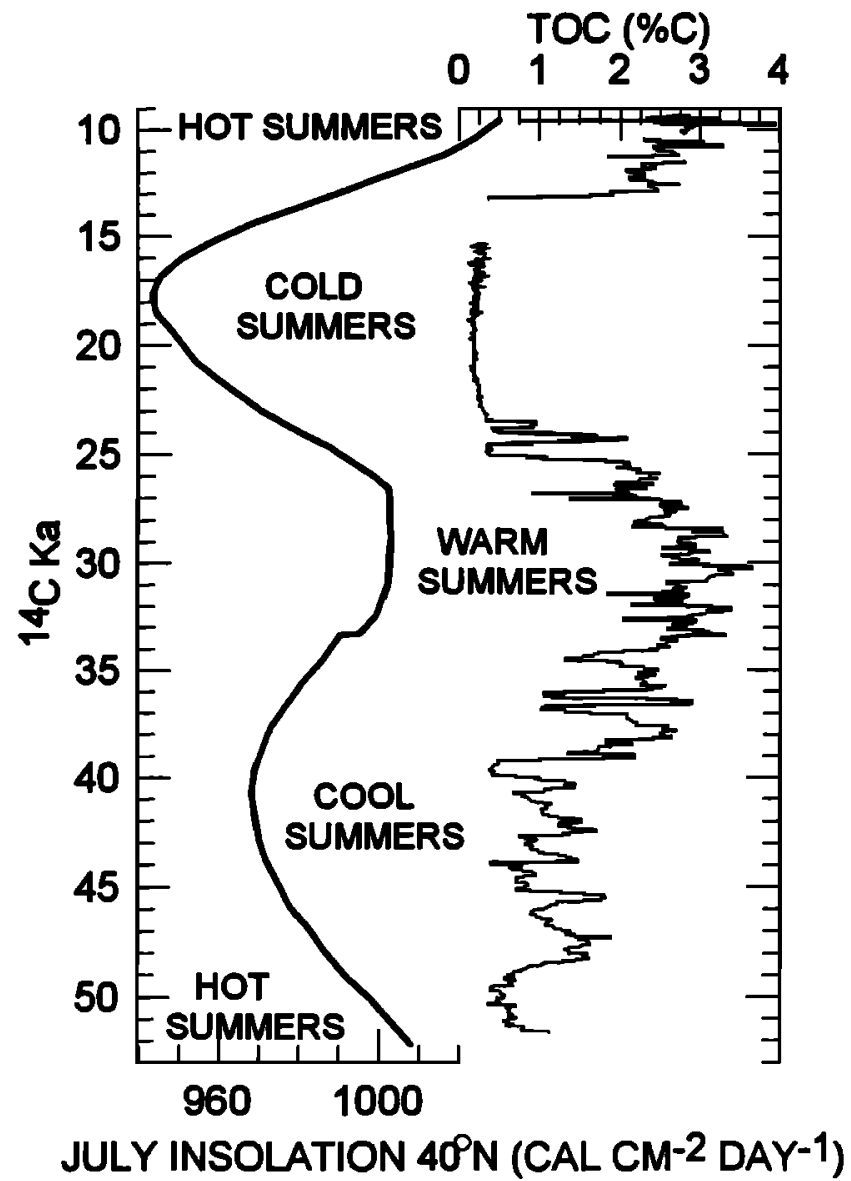

Figure 12. Plot comparing the TOC proxy for Sierran glaciation with July solar insolation at $40^{\circ} \mathrm{N}$. Note that summer temperatures appear to have modulated the size of alpine glaciers. 


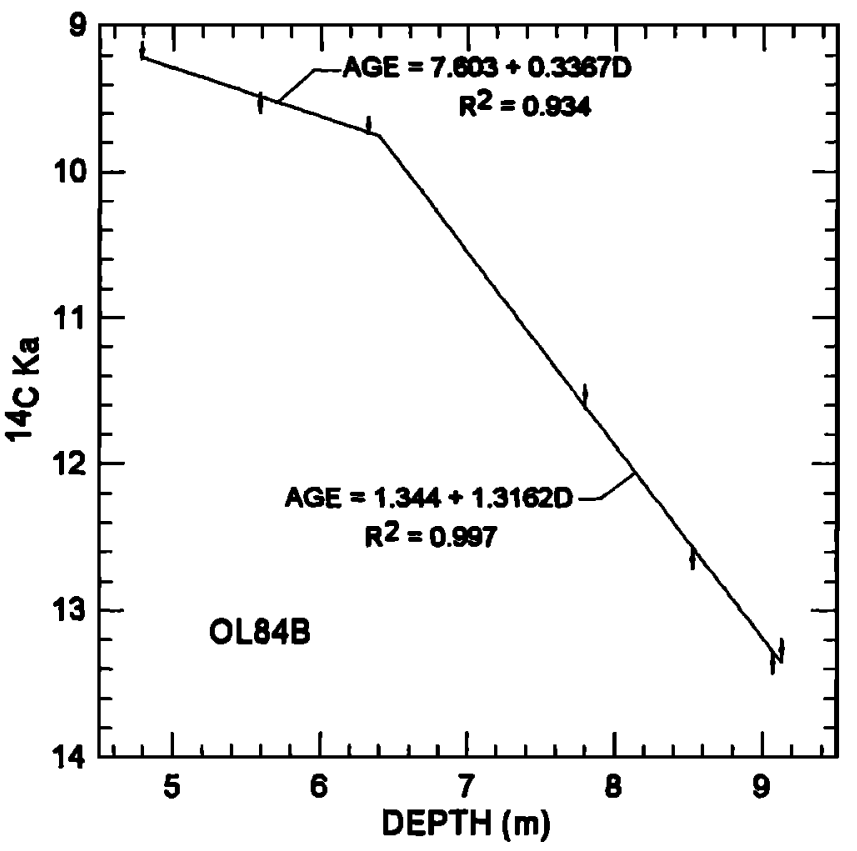

Figure 13. Linear-segment age model for OL84B between 4.79 and $9.13 \mathrm{~m}$.

climate of the Owens Lake basin was relatively dry during Heinrich events $\mathrm{H} 1$ and $\mathrm{H} 2$ (Figure 7). The Tioga glaciation occurred during an interval when Greenland's climate was very cold and relatively stable; i.e., oscillations in $\delta^{18} O$ were relatively minor. It is not possible to objectively correlate peaks in the Owens Lake TOC record (interstades) with Dansgaard-Oeschger interstades in the GISP2 $\delta^{18} \mathrm{O}$ record given uncertainties in age control and the difference in the shapes of the OL90 and GISP2 records. For example, the multimillennial asymmetric decreases in $\delta^{18} \mathrm{O}$ that follow DansgaardOeschger events D8, D12, and D14 have no counterpart in the Owens Lake records.

The $\delta^{18} \mathrm{O}$ data obtained in the study of OL84B indicate four wet-dry oscillations between $\sim 13.6$ and $9.0{ }^{14} \mathrm{C} \mathrm{ka}$ (Figure 10). During the 11.0 to $10.0{ }^{14} \mathrm{C} \mathrm{ka}$ Younger Dryas chronozone, the Owens basin appears to have experienced a wet-dry-wet $\left(W_{2}-D_{3}-W_{3}\right)$ oscillation in climate. The age model on which this conclusion is based does not provide a good fit to the age-depth data between 10.0 and $9.0{ }^{14} \mathrm{C}$ ka (Figure 11). To provide a different and perhaps more accurate age model, linear segments were fitted to the age-depth data between 13.4 and $9.2{ }^{14} \mathrm{C} \mathrm{ka}$ (Figure 13). Although the new age model results in a 200yr shift in the timing of the wet-dry oscillations, a climate oscillation $\left(W_{2}-D_{3}\right)$ still characterizes the Younger Dryas chronozone (Figure 14).

\section{Pyramid Lake}

Core PLC92B (40.8 to $12.5^{14} \mathrm{C} \mathrm{ka}$ ). In 1992, a 17.35$\mathrm{m}$ sediment core was taken from the Wizards Cove area of Pyramid Lake, Nevada (Figure 1). An age model for core PLC92B was obtained by fitting a $3^{\text {rt }}$-degree polynomial (Figure 15) to 12 of 14 samples from the ${ }^{14} \mathrm{C}$ age-depth data set.

A change from organic-rich to organic-poor sediments occurs at $\sim 24.5{ }^{14} \mathrm{C} \mathrm{ka}$, marking the beginning of the Tioga glaciation (Figure 16). Prior to $\sim 24.5{ }^{14} \mathrm{C}$ ka, millennialscale oscillations in TOC are evident. The TOC oscillations indicate productivity changes that accompanied the advance and retreat of Sierran glaciers. It is difficult to correlate TOC oscillations recorded in the Pyramid and Owens lakes basins (Figure 17). Both records, however,

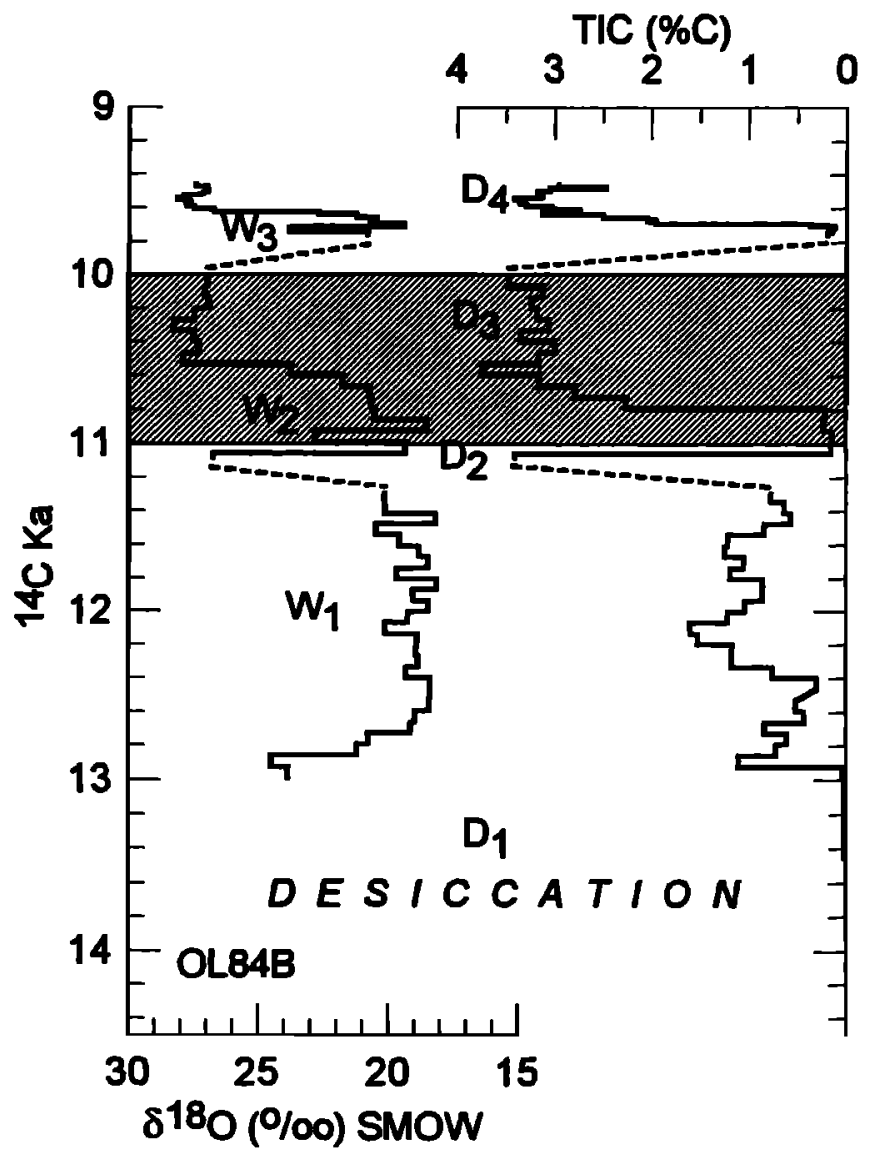

Figure 14. TIC and $\delta^{18} \mathrm{O}$ values of sediments from OL84B between 13.5 and $9.4{ }^{14} \mathrm{C}$ ka plotted using age control of Figure 13. This age model indicates that an abrupt wet-dry oscillation occurred during the Younger Dryas chronozone (shaded rectangle). 


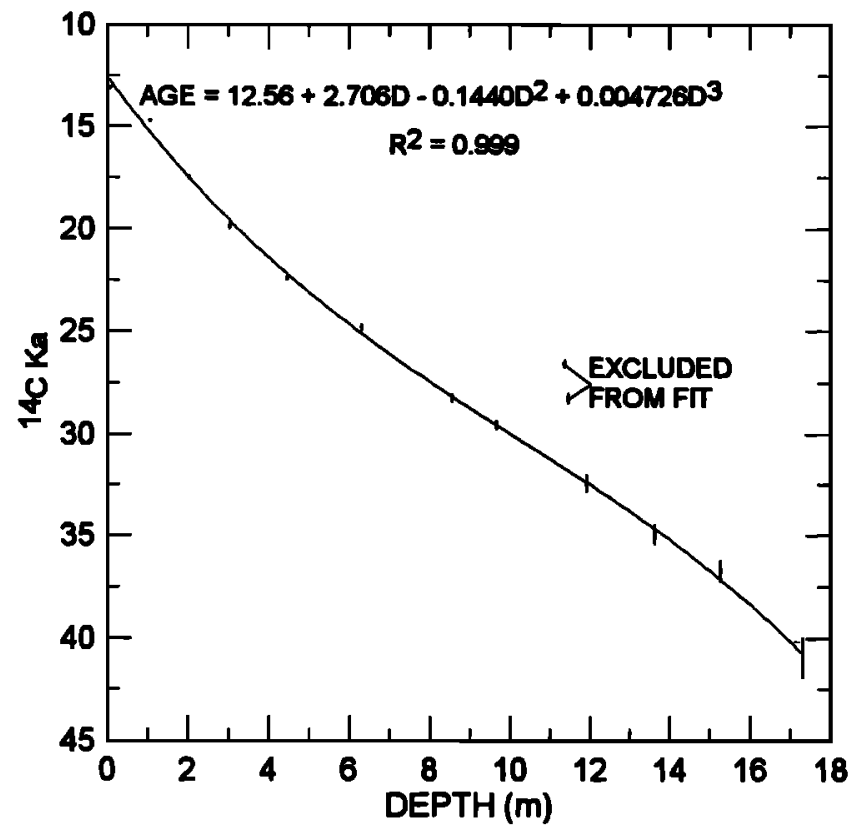

Figure 15. Radiocarbon age model for core PLC92B from Benson et al. [1998b]. Two samples excluded from polynomial fit may have organic carbon derived from roots.

indicate that between 10 and 13 TOC oscillations occurred between 40.0 and $\sim 24.5{ }^{14} \mathrm{C}$ ka.

The $\delta^{18} \mathrm{O}$ record for PLC92B indicates a series of oscillations, including several maxima (lowstands) and a prominent minimum (highstand) at $13.6{ }^{14} \mathrm{C}$ ka (Figure 16). Between 25.0 and $12.5{ }^{14} \mathrm{C} \mathrm{ka}$, the $\delta^{18} \mathrm{O}$ record matches the major features of the tufa based lake-level record (Figure 18, Benson et al., 1995), with lowstands at 23.0 and $14.5{ }^{14} \mathrm{C}$ ka and abrupt increases in lake size between 22.0 and $20.0{ }^{14} \mathrm{C} \mathrm{ka}$ and between 14.5 and 13.6 ${ }^{14} \mathrm{C} \mathrm{ka}$. The lowstand at $27.0{ }^{14} \mathrm{C}$ ka has also been observed in the tufa based $\delta^{18} \mathrm{O}$ record of figure 9 published in Benson et al. [1996b]. In general, however, it is difficult to explicitly associate features of the Pyramid Lake $\delta^{18} \mathrm{O}$ record with changes in hydrologic balance given the topographic complexity (three spill points) of the system (Figure 1).

Most of the TOC minima (stades) between 40.6 and $24.0{ }^{14} \mathrm{C}$ ka are associated with maxima in TIC and many of the TOC minima between 37.5 and $24.0{ }^{14} \mathrm{C}$ ka are associated with high values in $\delta^{18} \mathrm{O}$ (Figure 16). These relationships suggest that glacial introduction of silicate materials was not sufficient to mask the TIC signal in the Pyramid Lake basin and further implies that many of the alpine stades occurred during relatively dry times. The latter part of this conclusion is consistent with data from the Owens Lake basin between 52.6 and $40.0{ }^{14} \mathrm{C} \mathrm{ka}$, reinforcing the concept that alpine glacier advances occurred during relatively dry periods. However, some stades, e.g., S-8 and S-9 were accompanied by low TIC and low $\delta^{i 8} \mathrm{O}$ values suggesting relatively wet conditions. The fact that the PLC92B TIC record was not masked by glacially derived silicates prior to the Tioga glaciation may be due to one of more of the following processes: (1) glacier activity was weaker in the Truckee River catchments than in the Owens valley catchments, (2) substantial amounts of glacial debris were trapped in the Lake Tahoe basin, and (3) the location of PLC92B was far from the input source of silicate rock flour to Pyramid Lake.

It was previously noted (see above) that a dry-wet oscillation occurred in the Owens Lake basin during the Tioga glaciation (Figure 7). This oscillation is also evident in the $\delta^{18} \mathrm{O}$ and TIC records from PLC92B (Figure 16). In particular the TIC record of PLC92B exhibits a maximum between 24.4 and $21.3{ }^{14} \mathrm{C}$ ka that indicates a long shallow-lake interval.

\section{Comparison of Pyramid Lake Records with North Atlantic Climate Events}

Comparison of the PLC92B $\delta^{18} \mathrm{O}$ records with the GISP2 $\delta^{18} \mathrm{O}$ record indicates that the climate of the Pyramid Lake basin was relatively dry at about the times of Heinrich events $\mathrm{H} 1$ and $\mathrm{H} 2$ (Figure 16). It is, however, not possible to correlate objectively peaks in the Pyramid Lake TOC record (interstades) with Dansgaard-Oeschger interstades in the GISP2 $\delta^{18} O$ record, given uncertainties in age control and the difference in the shapes and amplitudes of the PLC92B and GISP2 records.

\section{Mono Lake}

Wilson Creek Formation (35.4 to $12.86{ }^{\prime \prime} \mathrm{C}$ ka). Mono Lake (Pleistocene Lake Russell) is a hydrologically closed lake located directly north of the Owens River drainage (Figure 1). Three streams (Lee Vining, Rush, and Mill Creeks) contribute most of the surface-water discharge to the lake. Mono Lake appears to have remained closed throughout the past $100 \mathrm{ka}$ [Lajoie, 1968].

The Wilson Creek Formation contains laminated muds and silts separated by 19 tephra layers (ashes) [Lajoie, 1968]. At the type section, sediments sandwiched between Ash 4 and 5 were eroded and reworked during a lowstand [Benson et al., 1998a]. At its South Shore site, the Wilson Creek Formation is thicker than at its type section and $17 \mathrm{~m}$ lower in elevation. At this site, sediments between Ash 4 and 5 remain unreworked. Nearly continuous sets of 2-cm-thick samples were taken from outcrop near the type section and from between Ashes 4 and 5 at the South Shore site for $\delta^{18} \mathrm{O}$ and TIC analyses.

An age model for sediments at the Wilson Creek type section was constructed using ${ }^{14} \mathrm{C}$ ages of carbonate 


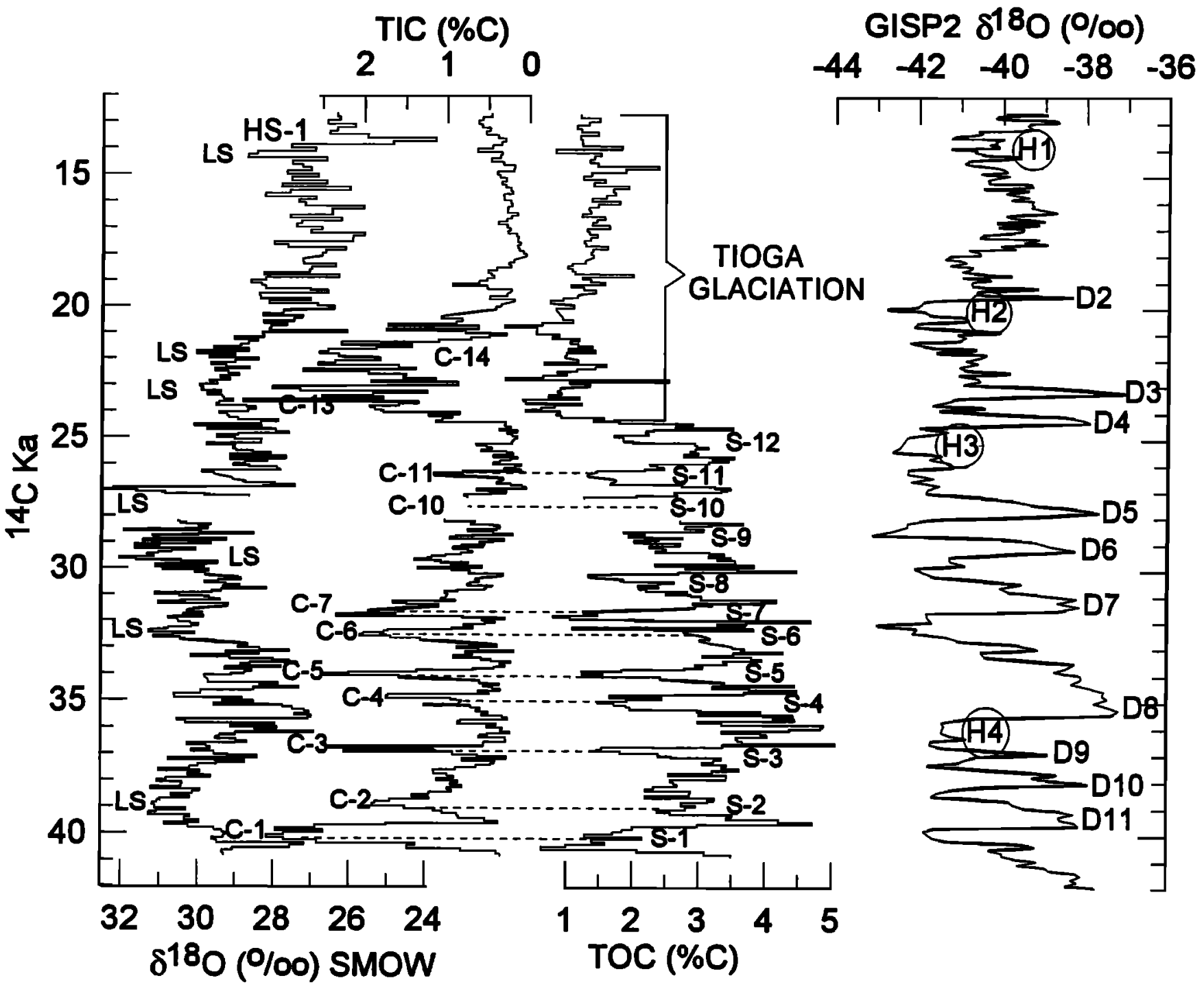

Figure 16. Pyramid Lake TIC, TOC and $\delta^{18} \mathrm{O}$ records compared with the $\delta^{18} \mathrm{O}$ record from GISP2. 'HS' refers to Lahontan highstand; LS refers to lowstands, 'S' refers to Sierran stades. ' $H$ ' refers to North Atlantic Heinrich events, and ' $D$ ' refers to Dansgaard-Oeschger interstades. Dotted lines indicate when Sierran stades occurred during periods of closure of Owens Lake; i.e., when the climate was cold and relatively dry .

samples [Table IV in Benson et al., 1990] collected from several localities along the Wilson Creek drainage by Ken Lajoie of the U.S. Geological Survey. To construct the age model, it was assumed that the location of a carbonate sample relative to its confining ash layers at the type section was the same as at the locality from which the sample was taken. Linear regressions of data between Ashes 1 and 4 and between Ashes 5 and 19 (Figure 19a) were used to estimate the ${ }^{14} \mathrm{C}$ ages of individual tephra layers [Table 1 in Benson et al., 1998a]. The estimated ash ages and two AMS ${ }^{14} \mathrm{C}$ determinations on ostracode shells from the isotope section were subsequently used to derive an age-depth relationship for the Wilson Creek isotope sampling site (Figure 19b). A linear age-depth relationship was applied to samples taken from the South Shore site.

Given the fit of the linear age-depth models and the questionable reliability of the porous carbonates that were dated, the uncertainties of the models are considered no better than a thousand years and the age of the older sediments may be underestimated by a few to several thousand years. 


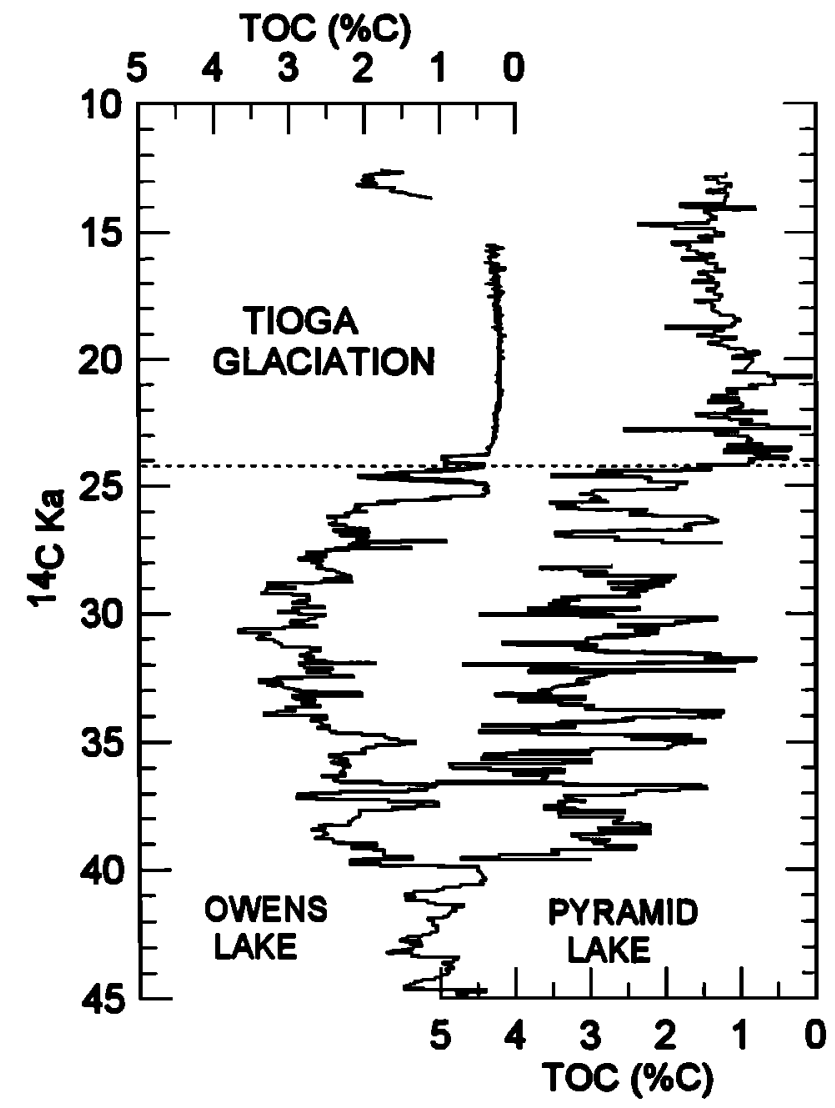

Figure 17. From Benson et al. [1998b]. Comparison of TOC indicators of glacial oscillations in cored sediments from the Owens and Pyramid lake basins. Note that TOC values are smaller after $24.5{ }^{14} \mathrm{C} \mathrm{ka}$, indicating dilution of the TOC fraction and suppression of productivity by glacial rock flour from the Tioga glaciation.

Most of the TOC in subaerially exposed Mono Lake sediments has been oxidized and is not suitable as a proxy of glacier activity. Low values of TIC between 26.0 and $14 .{ }^{14} \mathrm{C}$ ka probably reflect dilution of the TIC fraction by rock flour from the Tioga glaciation (Figure 20).

The $\delta^{18} \mathrm{O}$ record displays high-amplitude fluctuations with four principal maxima centered at 34, 27, 21 and 15 ${ }^{14} \mathrm{C}$ ka (Figure 20). The simplest interpretation of these maxima is that they represent lowstands. However, the maxima may also indicate approaches to closed-basin isotopic equilibrium that did not involve lake-volume decreases. Two major $\delta^{18} \mathrm{O}$ minima (highstands) occur at 18.0 and $13.0{ }^{14} \mathrm{C} \mathrm{ka}$

The TIC and $\delta^{18} \mathrm{O}$ records parallel each other between 35.5 and $26.0{ }^{14} \mathrm{C} \mathrm{ka}$, suggesting that glacier activity wasn't sufficient to mask the usefulness of the TIC record as a hydrologic proxy. The parallelism of both records supports the interpretation of $\delta^{18} \mathrm{O}$ maxima as lowstand indicators. Lowstands L3 and L4 are clearly expressed in the TIC records; however, glacially derived (Tioga) sediments obscure lowstands L1 and L2.

The 31 to $26{ }^{14} \mathrm{C}$ ka period was a time of increased carbonate deposition. Lowstand L4 was an exceptionally dry event; $-60 \%$ of the sediment deposited at that time was in the form of $\mathrm{CaCO}_{3}$. The dry-wet oscillation that occurred in the Owens Lake and Pyramid Lake basins after the onset of the Tioga glaciation (Figures 7 and 16) is also evident in the $\delta^{18} \mathrm{O}$ and TIC records from the Wilson Creek Formation (Figure 20).

The Mono Lake records are not useful in determining millennial-scale glacier oscillations; however, the $\delta^{18} \mathrm{O}$ and TIC records can be compared with the timing of Heinrich events if reliable age control for the Mono Lake records could be demonstrated. For this reason, Benson et al. [1998a] turned to another method of comparison to test the hypothesis that some Mono Lake lowstands and Heinrich events may have occurred at the same times.

Paleomagnetic field directional and intensity variations recorded in North Atlantic cores that contain evidence for Heinrich events were used to create a magnetic chronostratigraphy in which each Heinrich event was

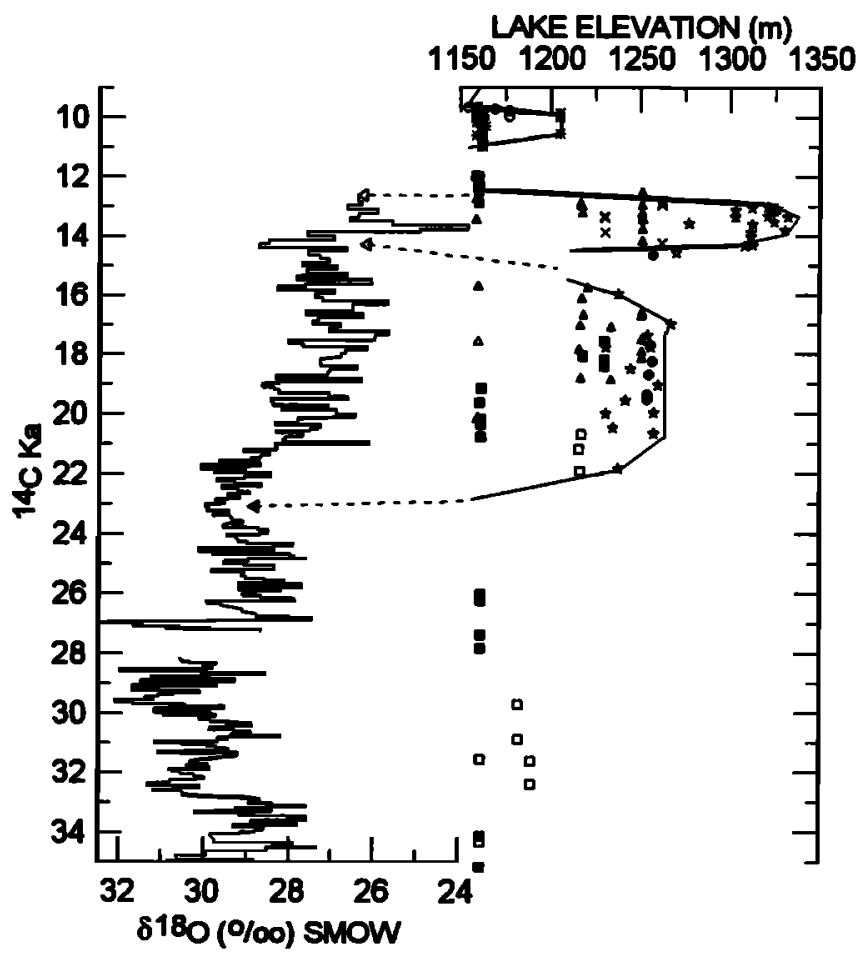

Figure 18. Comparison of Pyramid Lake $\delta^{18} \mathrm{O}$ record with carbonate based lake-level envelope for Lake Lahontan between 35.0 and $13.0{ }^{14} \mathrm{C} \mathrm{ka}$. Different symbols indicate differing styles of carbonate deposits discussed in Benson et al. [1995]. Dashed lines connect times of low lake levels observed in both records. 

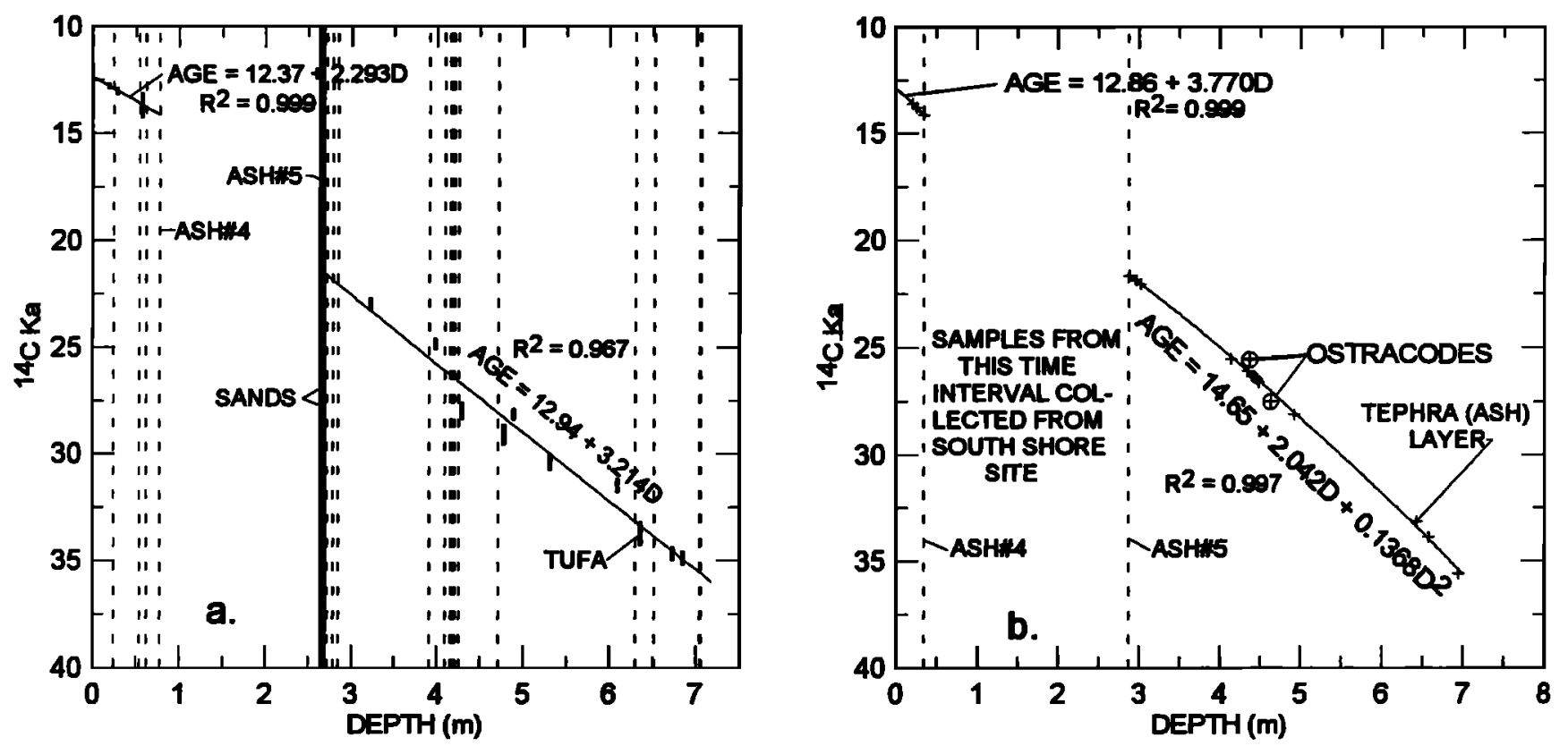

Figure 19. (a) From Benson et al. [1998a]. Radiocarbon ages and depths of carbonates in the Wilson Creek area used to estimate the ages of 19 tephra layers (ashes) exposed in the Wilson Creek Formation along Wilson Creek. Ashes are depicted as vertical dashed lines. Data used in this figure were taken from Wilson Creek type section listing in Table IV of Benson et al. [1990]. In the regression equations, D refers to depth in meters (m). In constructing the two regression lines, some samples from Table IV were rejected. Sample USGS-1435 came from the reworked Ash 4-5 interval. Radiocarbon ages of samples USGS-1436 and L-1167C were splits from the same collection of ostracode valves whose radiocarbon ages are anomalously young $\left(-23,000\right.$ instead of $\sim 26,000{ }^{14} \mathrm{C}$ yr). We expect that modern carbon was added to many of the thin-walled ostracode valves. The radiocarbon age of sample USGS-362, a nodular tufa with carbonate coatings from the base of the Wilson Creek Formation, was also clearly too young $\left(28,600\right.$ instead of $-36,000{ }^{14} \mathrm{C}$ yr). Sample USGS -276 was rejected because its ${ }^{14} \mathrm{C}$ age was infinite $\left(39,600{ }^{14} \mathrm{C} \mathrm{yr}\right)$. (b) From Benson et al. [1998a]. Radiocarbon age control for Wilson Creek isotope section. Age control is based on estimated ages of 18 tephra layers [Table 1 in Benson et al., 1998a]. The two ostracode AMS ${ }^{14} \mathrm{C}$ ages provide a check on the reliability of the tephra-derived age model for the interval 27.5 to $25.0{ }^{14} \mathrm{C} \mathrm{ka}$

associated with directional features of the magnetic records [Benson et al., 1998a]. North Atlantic intensity and directional records (both inclination and declination) were then correlated with Wilson Creek paleomagnetic secular variation (PSV) features to determine what Mono Lake $\delta^{18} \mathrm{O}$ features were associated with Heinrich events. From the PSV data, it appears that Heinrich events H1, H2, and H4 and Mono Lake lowstands L1, L2, and L4 overlap in time (Figures 20 and 21). Heinrich event H3, however, does not overlap any Mono Lake lowstand and there are other lowstands such as the one at $30.3 \mathrm{ka}$ that bear no relation to Heinrich events.

\section{SUMMARY AND CONCLUSIONS}

During the past $150,000 \mathrm{yr}$, the Great Basin witnessed intervals that were dominantly glacial/interglacial or pluvial/interpluvial (wet/dry); however, none of the intervals were climatically monotonic on the millennial scale. $5000 \pm$ yr wet periods occurred during the last interpluvial and 5000 \pm yr interstades occurred during glacial intervals (Figure 2). A comparison of the Owens Lake medium-resolution records [Bischoff et al., 1997a; Menking et al., 1997] with the SPECMAP $\delta^{18} \mathrm{O}$ proxy for continental ice volume (Figure 2) indicates that the last alpine interglacial (121 to $62 \mathrm{ka}$ ) did not occur at the same time as the last continental interglacial (stage 5e, 128 to $115 \mathrm{ka})$ nor did it occur at the same time as stage 5 (128 to $71 \mathrm{ka}$ ) when continental ice volumes were relatively small. In addition, the Owens Lake $\delta^{18} \mathrm{O}$, TIC, and $\mathrm{Na}_{2} \mathrm{O}$ records have rectilinear shapes and bear little similarity to the sawtooth shaped marine $\delta^{18} O$ record.

Studies of Greenland ice cores and North Atlantic sediments indicate that centennial-to-millennial-scale climate variability occurred often during the last ice age. Hydrologic-balance records from each of the three lake 


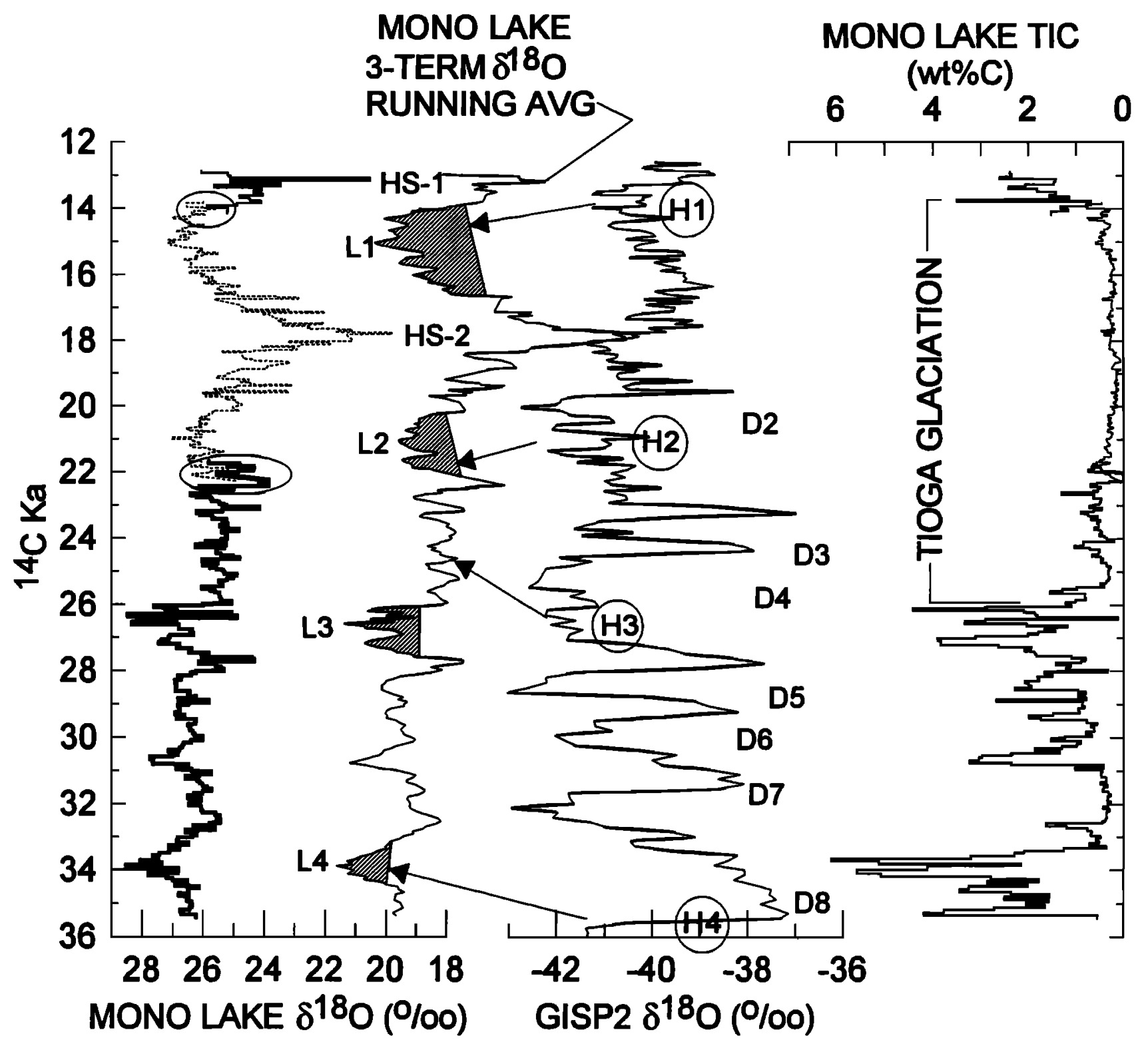

Figure 20. Modified from Benson et al. [1998a]. Mono Lake TIC and $\delta^{18} \mathrm{O}$ records compared with the $\delta^{18} \mathrm{O}$ record from GISP2. ' $L$ ' refers to lowstands of Mono Lake; circled ' $H$ ' refers to North Atlantic Heinrich events; ' $D$ ' refers to Dansgaard-Oeschger stades and 'HS' refers to highstands of Mono Lake at 18.0 and $13.0{ }^{14} \mathrm{C}$ ka Arrows point to the location of Heinrich events in the Mono Lake records based on comparison of paleomagnetic secular variation waveforms in North Atlantic cores and Mono Lake (Wilson Creek) sediments (see Figure 21). Low TIC values between 25.0 and $14.0{ }^{14} \mathrm{C} \mathrm{Ka}$ indicate dilution of TIC fraction by Tioga-age glaciers.

basins and alpine-glacial records from Owens and Pyramid Lake exhibit millennial-scale variability (Figures 6, 7, 10, 16, 17, 20). In the Owens Lake basin, the highest amplitude oscillations in hydrologic balance occurred near the beginning and end of the last Sierran alpine glacial period when major changes in the large-scale pattem of atmospheric circulation were occurring in response to rapid growth and destruction of the Laurentide Ice Sheet. Climate records from the Owens and Pyramid Lake basins indicate that most, but not all, glacier advances (stades) occurred during relatively dry times (Figures 7,16 ).

In the North Atlantic region, some climate records have clearly defined variability/cyclicity (e.g., DansgaardOeschger and Heinrich events) with periodicities of $10^{2}$ to 


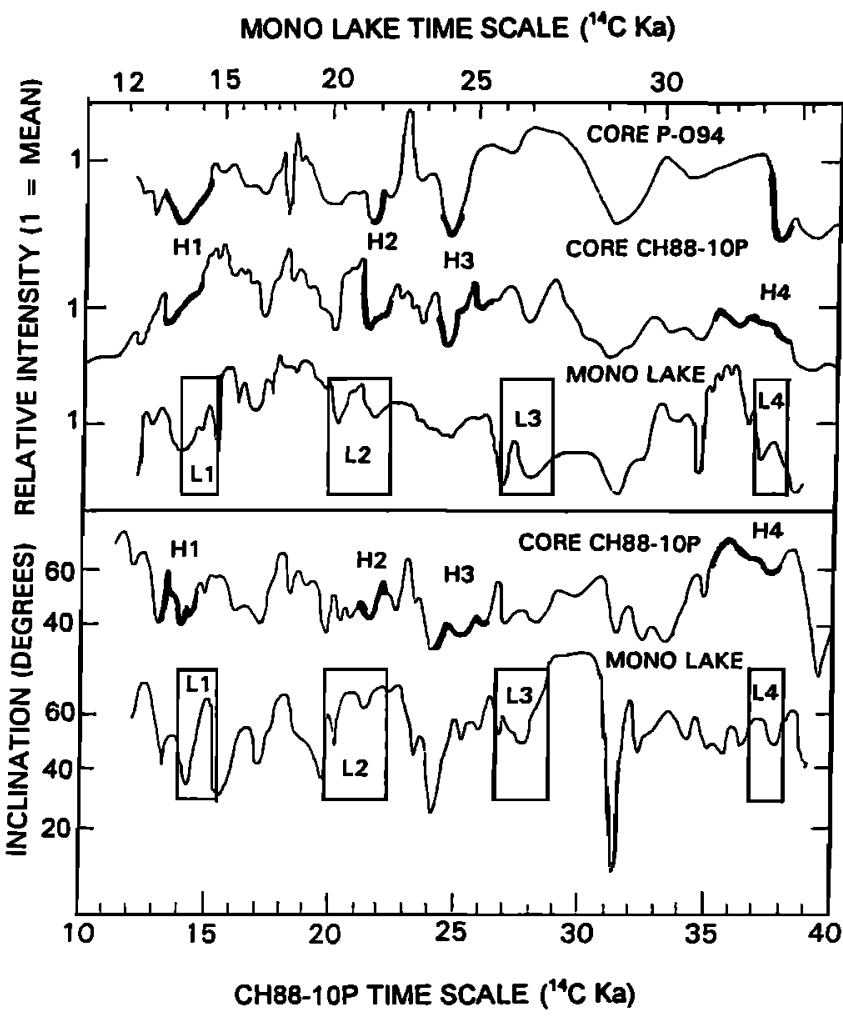

Figure 21. Modified from Benson et al. [1998a]. Comparison of Heinrich event and Mono Lake lowstand ages using paleomagnetic field variability (intensity and inclination) for chronostratigraphic control. Methodology for placement of the Heinrich events on the paleomagnetic waveforms is discussed in Benson et al., [1998a]. The stratigraphic locations of Heinrich events in North Atlantic cores CH8810P, and P-094 are indicated by thick black lines labeled H1 through H4. Mono Lake lowstands are shown as rectangles labeled L1 through L4. The paleomagnetic data indicate that Heinrich events $\mathrm{H} 1, \mathrm{H} 2$, and $\mathrm{H} 4$ occurred during Mono lowlake intervals, whereas Heinrich event $\mathrm{H} 3$ did not. Note that the durations of the lowstands and accompanying Heinrich events differ. The ${ }^{14} \mathrm{C}$ chronology for CH88-10P [Keigwin and Jones, 1989; Keigwin 1994] was used to develop a common time scale for the marine records). Radiocarbon ages of Mono Lake sediments are shown in the upper abscissa and radiocarbon ages of marine sediments are shown in the lower abscissa. Declination data (not shown) were also used in the construction of this diagram.

$10^{3} \mathrm{yr}$ and these records are correlatable over several thousand $\mathrm{km}$. In the Great Basin, climate proxies also have clearly defined variability with similar (and even smaller) periodicities, but the distance over which this variability can be correlated remains unknown. Globally, there may be minimal spatial scales (domains) within which climate varies coherently on centennial and millennial scales. The sizes of those domains change with location and the time constant of climate forcing. A more thorough understanding of the mechanisms of climate forcing and the physical linkages between climate forcing and system response is needed in order to predict the spatial scale(s) over which climate varies coherently.

A question remains as to whether oscillations in the sizes of Great Basin glaciers and lakes can or should be linked to climatic oscillations documented in the North Atlantic region. Some data suggests that the Owens Lake basin was relatively dry during Heinrich events $\mathrm{H} 1, \mathrm{H} 2$, and $\mathrm{H} 4$ (Figure 20). In addition, each of the lakes discussed in this paper experienced relatively low levels at the times of $\mathrm{Hl}$ and $\mathrm{H} 2$ (Figure 22). The presence of lakelevel minima in all three lake basins at $\sim 21$ and $\sim 14 \mathrm{ka}$ as well as lake-level maxima at $\sim 18$ and $13 \mathrm{ka}$ may, however, have resulted from an oscillation in the mean position of

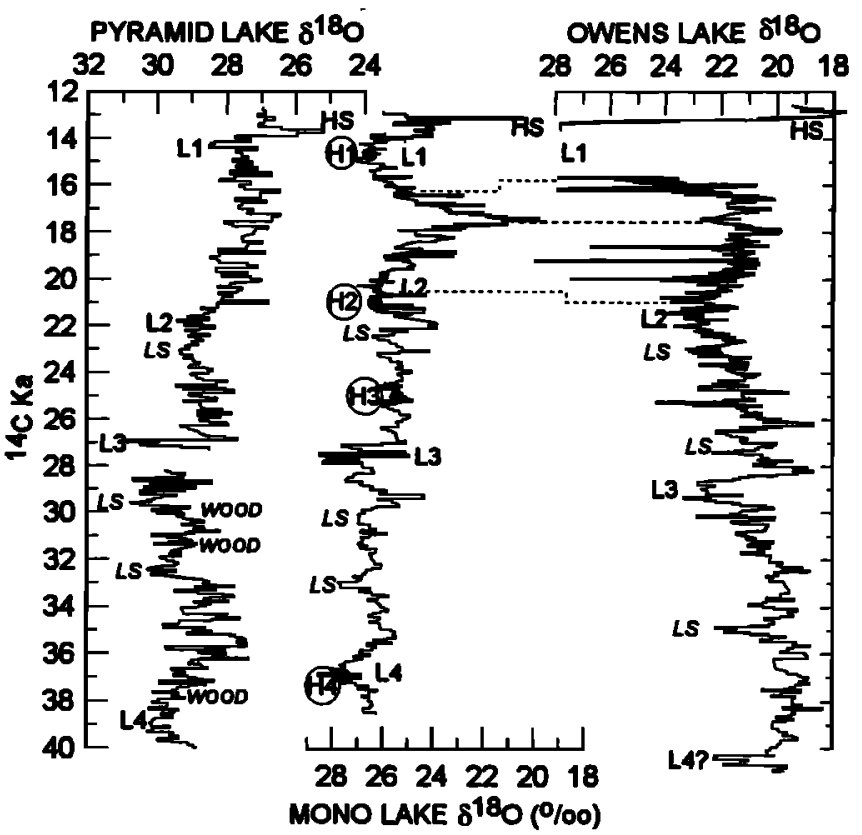

Figure 22. Comparison of Pyramid, Mono and Owens Lake $\delta^{18} \mathrm{O}$ data for the period 40.0 to $\sim 12.5{ }^{14} \mathrm{C}$ ka ' $\mathrm{L}$ ' refers to prominent lowstands in the three basins; ' $L S$ ' refers to other unnumbered lowstands; ' $H$ ' and solid circles $(\bullet)$ denote the paleomagnetic secular variation (PSV) based positions of Heinrich events in the Mono Lake record; and 'HS' indicates the last major highstand/overflow event in each of the three basins. 'WOOD' indicates times when tufa coated roots were found at low elevations around the Pyramid Lake basin [Benson et al., 1995]. The location of Heinrich events in the Mono Lake section are based on a PSV match with CH88-10P and P-094 (see Figures 20 and 21]. The chronology of the Wilson Creek section has been stretched to match the ${ }^{14} \mathrm{C}$ dates for Heinrich events $\mathrm{H} 1$ through $\mathrm{H} 4$ in CH88-10P [Keigwin, 1989, 1994]. The dotted lines indicate PSV correlations between Mono Lake and Owens Lake sediments (unpublished data of S. Lund). 
the PJS that occurred in response to the gradual change in size of the Laurentide Ice Sheet [Benson et al., 1995].

Alpine glaciers and surface-water systems do not come to instantaneous equilibrium with a new climate state. The more abrupt the change in climate and the larger its departure from the existing climate state, the greater the time the system will take to come to equilibrium. I abrupt changes in climate occur frequently, glacier and surface-water systems never achieve complete equilibrium with the climate system. The scale of these lag times must be determined if accurate comparisons of proxy records from marine, lacustrine and alpine glacier systems are to be made. This can best be done using numerical models that link changes in lake and glacier sizes to changes in the elements of climate.

Intrahemispheric correlation of marine and continental records will remain more of an art than a science until problems of age control can be minimized. The use of PSV holds promise but the spatial scale over which PSV varies coherently is yet to be demonstrated. Given existing problems with age control, intrahemispheric comparisons of proxy climate records can at least be made with regard to the number and duration of oscillations over a given time interval. With regard to this study, the number and durations of oscillations in $\delta^{18} \mathrm{O}$, TIC, TOC, and MS recorded in sediments from the Owens, Pyramid, and Mono basins are not the same as the number and durations of oscillations in $\delta^{18} \mathrm{O}$ documented in the GISP2 ice core (Figures $7,16,20$ ). These observations indicate that abrupt climate changes in the Northern Hemisphere during the Wisconsin occurred on millennial scales but that climate change was not spatially uniform.

On the global scale, it is possible to demonstrate that the climate of one time slice is everywhere colder/warmer than another time slice if average climates of rather long time slices are compared. Most, and perhaps all, global climate records indicate that Stage 2 was colder than Stage 1. However, as the synoptic climates of thinner time slices are compared, spatial heterogeneity of temperature fields soon become apparent; i.e., the spatial heterogeneity within each time slice begins to approach the weather endmember of the climate spectrum as the time slice increases in resolution.

One climate teleconnection that has been invoked in explaining the rise and fall of Great Basin lakes is the PJS. The PJS can be thought of as a teleconnection that links hemispheric weather anomalies along a moderately narrow band. In general, the precipitation field is not only inhomogeneous it is also discontinuous in nature. Today, the width of the precipitation anomaly associated with the PJS spans $\sim 2000 \mathrm{~km}$ [Starrett, 1949]. Climate is colder north and warmer south of the PJS core and wetter under the core, implying that regions of uniform and synchronous climate change in the Northern Hemisphere associated with the statistical position of PJS may take the form of irregularly shaped bands. If this conjecture is correct,
Dansgaard-Oeschger events cannot be linked with alpine glacier and lake-size fluctuations throughout the westem United States because the trajectory and intensity of the climate signal that connects Greenland to the western United States varied in space and time.

Evidence for even regional nonuniformity of climate change is apparent in hydrologic balance records from the Great Basin. Oxygen-18 records from Owens, Mono, and Pyramid Lake basins indicate that all three basins witnessed a wet-dry-wet oscillation in climate between 18.0 and $13.0{ }^{14} \mathrm{C} \mathrm{ka}$. However, there appears to have been a profound north-south gradient in the effective wetness of the lake basins during the dry period. Owens Lake completely desiccated $\sim 14.0{ }^{14} \mathrm{C}$ ka (Figure 7); but the surface of Mono Lake stood higher than at any time in the historical period (above the South Shore site) and Pyramid Lake data show only a moderate increase in $\delta^{18} O$ (Figure 16).

$\delta^{18} \mathrm{O}$ and TOC records from the Owens Lake basin indicate that substantial wet-dry oscillations occurred during what may be interpreted as generally cold stades (52.0 to 49.0 and 24.0 to $14.0{ }^{14} \mathrm{C} \mathrm{ka}$ )(Figures 7 and 8). This suggests that precipitation and temperature variations were not phase locked.

One of the more interesting findings of this study and those that preceded it [Benson et al., 1996a, Benson et al., 1997] is that different frequencies of climate change have different polarity combinations; e.g., a climate frequency which varies from cold-wet to warm-dry versus a frequency that varies from cold-dry to warm-wet. The mediumresolution Owens Lake records of Bischoff et al. [1997a] and Menking et al. [1997](Figure 2) show quite clearly that cold-wet alpine glaciations alternated with warm-dry interglacials on Milankovitch time scales. The highresolution Owens Lake records (Figures 7 and 8) of Benson et al. [1996a] show that during the last alpine glacier interval, cold-dry stades alternated with warm-wet interstades on millennial (Dansgaard-Oeschger) time scales.

Acknowledgments. The author is grateful for reviews of this manuscript by John Andrews, Jim Dungan Smith, Jack Oviatt, and John Flager.

\section{REFERENCES}

Adams, D.K., and A.C. Comrie, The North American Monsoon, Bulletin of the American Meteorological Society, 78, 2197-2213, 1997.

Allen, B.D., and R.Y. Anderson, Evidence from western North America for rapid shifts in climate during the last Glacial Maximum, Science, 260, 1920-1923, 1993.

Bard, E., M. Amold, R.G. Fairbanks, and B. Hamelin, ${ }^{230} \mathrm{Th}-$ ${ }^{234} \mathrm{U}$ and ${ }^{14} \mathrm{C}$ ages obtained by mass spectrometry on corals, Radiocarbon, 35 (1), 191-199, 1993.

Bard, E., B. Hamelin, M. Amold, L. Montaggioni, G. Cabioch, G. Faure, and F. Rougerie, Deglacial sea-level record from 
Tahiti corals and the timing of global meltwater discharge, Nature, 382, 241-244, 1996.

Bard, E., B. Hamelin, R.G. Fairbanks, and A. Zindler, Calibration of the ${ }^{14} \mathrm{C}$ time scale over the past 30,000 years using mass spectrometric U-Th ages from Barbados corals, Nature, 345, 405-410, 1990.

Beanland, S., and M. Clark, The Owens Valley fault zone, eastern California, and surface rupture associated with the 1872 earthquake, in U.S. Geological Survey Bulletin 1982, pp. $29,1994$.

Behl, R.J., and J.P. Kennett, Brief interstadial events in the Santa Barbara Basin, Northeastern Pacific, during the past $60 \mathrm{kyr}$, Nature, 379, 243-246, 1996.

Benson, L.V., Stable isotopes of oxygen and hydrogen in the Truckee River-Pyramid Lake surface-water system. 1. Data analysis and extraction of paleoclimatic information, Limnology Oceanography, 39, 344-355, 1994.

Benson, L.V., J. Burdett, S. Lund, M. Kashgarian, and S. Mensing, Nearly synchronous climate change in the Northern hemisphere during the last glacial termination, Nature, 388, 263-265, 1997.

Benson, L.V., J.W. Burdett, M. Kashgarian, S.P. Lund, F.M. Phillips, and RO. Rye, Climatic and Hydrologic oscillations in the Owens Lake Basin and adjacent Sierra Nevada, California, Science, 274, 746-749, 1996a.

Benson, L.V., D.R. Currey, R.I. Dorn, K.R. Lajoie, C.G. Oviatt, S.W. Robinson, G.I. Smith, and S. Scott, Chronology of expansion and contraction of four Great Basin lake systems during the past 35,000 years, Palaeogeography, Palaeoclimatology, Palaeoecology, 78, 241-286, 1990.

Benson, L.V., M. Kashgarian, and M. Rubin, Carbonate deposition, Pyramid Lake subbasin, Nevada. 2. Lake levels and polar jet stream positions reconstructed fium radiocarbon ages and elevations of carbonates (tufas) deposited in the Lahontan Basin, Palaeogeography, Palaeoclimatology, Palaeoecology, 117, 1-30, 1995.

Benson, L.V., and H. Klieforth, Stable isotopes in precipitation and ground water in the Yucca Mountain region, southern Nevada: Paleoclimatic implications, in Aspects of Climate Variability in the Pacific and Western Americas, edited by D.H. Peterson, pp. 41-59, 1989.

Benson, L.V., S.P. Lund, J.W. Burdett, M. Kashgarian, T.P. Rose, J.P. Smoot, and M. Schwartz, Correlation of LatePleistocene lake-level oscillations in Mono Lake, California, with North Atlantic climate events, Quaternary Research, 49, I-10, 1998a.

Benson, L.V., H.M. May, R.C. Antweiler, T.I. Brinton, M. Kashgarian, J.P. Smoot, and S. P. Lund, Continuous lakesediment records of glaciation in the Sierra Nevada between 52,600 and $12,500{ }^{14} \mathrm{C}$ yr B.P., Quaternary Research, 50, 113-127, 1998 b.

Benson, L.V., P.A. Meyers, and R.J. Spencer, Change in the size of Walker Lake during the past 5000 years, Palaeogeography, Palaeoclimatology, Palaeoecology, 81, 189-214, 1991.

Benson, L.V., and Z. Peterman, Carbonate deposition, Pyramid Lake subbasin, Nevada: 3 . The use of ${ }^{87} \mathrm{Sr}$ values in carbonate deposits (tufas) to determine the hydrologic state of paleolake systems, Palaeogeography, Palaeoclimatology, Palaeoecology, 119, 201-213, 1995.

Benson, L.V., L.D. White, and R Rye, Carbonate deposition,
Pyramid Lake Subbasin, Nevada: 4. Comparison of the stable isotope values of carbonate deposits (tufas) and the Lahontan lake-level record, Palaeogeography, Palaeoclimatology, Palaeoecology, 122, 45-76, $1996 \mathrm{~b}$.

Bischoff, J.L., K.M. Menking, J.P. Fitts, and J.A. Fitzpatrick, Climatic oscillations $10,000-155,000$ yr B.P. at Owens Lake, Califomia, reflected in glacial rock flour abundance and lake salinity in Core OL-92, Quaternary Research, 48, 313-325, 1997a.

Bischoff, J.L., T.W. Stafford, and M. Rubin, A time-depth scale for Owens Lake sediments of core OL-92: Radiocarbon dates and constant mass-accumulation rate, in $A n$ 800,000 year paleoclimatic record from Core OL-92, Owens Lake, Southeast California, edited by G.I. Smith, and J.L. Bischoff, pp. 91-98, $1997 \mathrm{~b}$.

Bond, G., W. Broecker, S. Johnsen, J. McManus, L. Labeyrie, J. Jouzel, and G. Bonani, Correlations between climate records from North Atlantic sediments and Greenland ice, Nature, $365,143-147,1993$.

Bond, G., H. Heinrich, W. Broecker, L. Labeyrie, J. McManus, J. Andrews, S. Houn, R. Jantschik, S. Clasen, C. Simet, K. Tedesco, M. Kias, G. Bonani, and S. Ivy, Evidence for massive discharges of icebergs into the North Atlantic ocean during the last glacial period, Nature, 360, 245-249, 1992.

Bond, G., W. Showers, M. Cheseby, R. Lotti, P. Almasi, P. deMenocal, P. Priore, H. Cullen, I. Hajdas, and G. Bonani, A pervasive millennial-scale cycle in North Atlantic Holocene and glacial climates, Science, 278, 1257-1266, 1997.

Bond, G.C., and R. Lotti, Iceberg discharges into the North Atlantic on millennial time scales during the last glaciation, Science, 267, 1005-1010, 1995.

Broecker, W.S., and A. Kaufman, The geochemistry of ${ }^{14} \mathrm{C}$ in freshwater systems, Geochemistry, 16, 15-38, 1959.

Brook, E.J., T. Sowers, and J. Orchanrdo, Rapid variations in Atmospheric methane concentration during the past 110,000 Years, Science, 273, 1087-1091, 1996.

Clark, D.H., Extent timing and climatic significance of latest Pleistocene and Holocene glaciation in the Sierra Nevada, California, unpublished doctoral thesis, University of Washington, Washington, 1995.

Clark, D.H., A new alpine lacustrine sedimentary record fiom the Sierra Nevada: Implications for late-Pleistocene paleoclimate reconstructions and cosmogenic isotope production rates, 1997.

Clark, D.H., P.R. Bierman, and P. Larsen, Improving in situ cosmogenic chronometers, Quaternary Research, 44, 367$377,1995$.

Clark, D.H., and A.R. Gillespie, Timing and significance of late-glacial and Holocene cirque glaciation in the Sierra Nevada, Califomia, Quaternary International, 38/39, 21 38, 1997.

Dansgaard, W., S.J. Johnsen, H.B. Clausen, D. Dahl-Jensen, N. Gundestrup, C.U. Hammer, and H. Oeschger, North Atlantic climatic oscillations revealed by deep Greenland ice cores, in Climate Processes and Climate Sensitivity, edited by J.E. Hansen, and T. Takahashi, pp. 288-298, AGU, Washington, D.C., 1984.

Dansgaard, W., S.J. Johnsen, H.B. Clausen, D. Dahl-Jensen, N.S. Gundestrup, C.U. Hammer, C.S. Hvidberg, J.P. 
Steffensen, A.E. Sveinbjornsdottir, J. Jouzel, and G. Bond, Evidence for general instability of past climate from a 250 kyr ice-core record, Nature, 364, 218-364, 1993.

Dansgaard, W., S.J. Johnsen, H.B. Clausen, and C.C. Langway Jr., Climate record revealed by the Camp Century ice core, in The Late Cenozoic Glacial Ages, edited by K.K. Turekian, pp. 37-56, Yale University Press, New Haven, 1971.

Dixon, T.H., J.L. Robaudo, J. Lee, and M.C. Reheis, Constraints on present-day basin and range deformation from space geodesy, Tectonics, 14, 755-772, 1995.

Dohrenwend, J.C., Nivation landforms in the western Great Basin and their paleoclimatic significance, Quaternary Research, 22, 275-288, 1984.

Font, K.R, Geochemical and Isotopic Evidence for Hydrologic Processes at Owens Lake, California, Master thesis, University of Nevada, Reno, 1995.

Galat, D.L., E.L. Lider, S. Vigg, and S.R. Robertson, Limnology of a large, deep, North American terminal lake, Pyramid Lake, Nevada, USA, Hydrobiologia, 82, 281-317, 1981.

Gale, H.S., Notes on the Quaternary lakes of the Great Basin with special reference to the deposition of potash and other salines, U.S. Geological Survey Bulletin 540-N, 399-406, 1914.

Grootes, P.M., M. Stuiver, J.W.C. White, S. Johnsen, and J. Jouzel, Comparison of oxygen isotope records from the GISP2 and GRIP Greenland ice cores, Nature, 366, 552$554,1993$.

Hallet, B., L. Hunter, and J. Bogen, Rates of erosion and sediment evacuation by glaciers: A review of field data and their implications, Global and Planetary Change, 12, 213 235, 1996.

Hinkley, T., Alkali and alkaline earth metals: Distribution and loss in a High Sierra Nevada watershed, Geological Society of America Bulletin, 85, 1333 - 1338, 1974.

Horn, L.H., and R.A. Bryson, Harmonic analysis of the annual march of precipitation over the United States, Annals of the Association of American Geographers, 50, 157-171, 1960.

Huber, N.K., Amount and time of late Cenozoic uplift and tilt of central Sierra Nevada, California, U.S. Geological Survey Professional Paper 1197, pp. 1-28, 1981.

Hughen, K.A., J.T. Overpeck, L.C. Peterson, and S. Trumbore, Rapid climate changes in the tropical Atlantic region during the last deglaciation, Nature, 380, 51-54, 1996.

Imbrie, J., J.D. Hays, D.G. Martinson, A. McIntyre, A.C. Mix, J.J. Morley, N.G. Pisias, W.L. Prell, and N.J. Shackleton, The orbital theory of Pleistocene climate: Support from a revised chronology of the marine $d^{18} \mathrm{O}$ record, Milankovitch and Climate, Part 1 (NATO ASI Series C), 126, $269-305,1984$.

Johnsen, S.J., H.B. Clausen, W. Dansgaard, K. Fuhrer, N. Gundestrup, C.U. Hammer, P. Iversen, J. Jouzel, B. Stauffer, and J.P. Steffensen, Irregular glacial interstadials recorded in a new Greenland ice core, Nature, 359, 311-313, 1992.

Johnsen, S.J., W. Dansgaard, H.B. Clausen, and J. Langway, C.C., Oxygen isotope profiles through the Antarctic and Greenland ice sheets, Nature, 235, 429-434, 1972.

Keigwin, L.D., and G.A. Jones, Glacial-Holocene stratigraphy, chronology, and paleoceanographic observations on some north Atlantic sediment drifts, Deep Sea Research, 36, 845-867, 1989.
Keigwin, L.D., and G.A. Jones, Western north Atlantic evidence for millennial-scale changes in ocean circulation and climate, Journal of Geophysical Research, 99, 1239712410, 1994.

Kitagawa, H., and J. van der Plicht, Atmospheric radiocarbon calibration to 45,000 yr B.P.: late glacial fluctuations and cosmogenic isotope production, Science, 279, 1187-1190, 1998.

Lajoie, K.R., Late quaternary stratigraphy and geologic history of Mono Basin Eastern California, Doctoral thesis, University of California, Berkeley, 1968.

Liddicoat, J.C., Mono Lake excursion in Mono Basin, California, and at Carson Sink and Pyramid Lake, Nevada, Geophysical Journal, International, 108, 442-452, 1992.

Liddicoat, J.D., and R.S. Coe, Mono Lake Geomagnetic Excursion, Journal of Geophysical Research, 84, 261-271, 1979.

Lin, J.C., W.S. Broecker, S.R. Hemming, I. Hajdas, R.F. Anderson, G.I. Smith, M. Kelley, and G. Bonani, A reassessment of U-Th and ${ }^{14} \mathrm{C}$ ages for late-glacial highfrequency hydrological events at Searles Lake, California, Quaternary Research, 49, 11-23, 1998.

Lund, D.C., and A.C. Mix, Millennial-scale deep water oscillations: Reflection of the North Atlantic in the deep Pacific from 10 to $60 \mathrm{ka}$, Paleoceanography, 13, 10-19, 1998.

Lund, S.P., Paleomagnetic secular variation, in Trends in Geophysical Research, pp. 423-438, Council of Scientific Research Integration, Trivandrum, India, 1993.

Lund, S.P., A comparison of Holocene paleomagnetic secular variation records from North America, Journal of Geophysical Research, 101, 8007-8024, 1996.

Lund, S.P., J.C. Liddicoat, K.R. Lajoie, T.L. Henyey, and S.W. Robinson, Paleomagnetic evidence for long-term ( $10^{4}$ year) memory and periodic behavior in the Earth's core dynamo process, Geophysical Research Letters, 15, 1101-1104, 1988.

Mayewski, P.A., L.D. Meeker, S. Whitlow, M.S. Twickler, M.C. Morrison, P. Bloomfield, G.C. Bond, R.B. Alley, A.J. Gow, P.M. Grootes, D.A. Meese, M. Ram, K.C. Taylor, and W. Wumkes, Changes in atmospheric circulation and ocean ice cover over the North Atlantic during the last 41,000 years, Science, 263, 1747-1751, 1994.

Menking, D.M., J.L. Bischoff, and J.A. Fitzpatrick, Climatic/Hydrologic Oscillations since 155,000 yr B.P. at Owens lake, Califomia, reflected in abundance and stable isotope composition of sediment carbonate, Quaternary Research, 48, 58-68, 1997.

Negrini, R.M., J.O. David, and K.L. Verosub, Mono Lake geomagnetic excursion found at Summer Lake, Oregon, Geology, 12 (643-646), 1984.

Oviatt, C.G., Lake Bonneville fluctuations and global climate change, Geology, 25, 155-158, 1997.

Phillips, F.M., A.R. Campbell, G.I. Smith, and J.L. Bischoff, Interstadial climatic cycles: A link between western North American and Greenland?, Geology, 22, 1115-1118, 1994.

Phillips, F.M., L.A. Peeters, and M.K. Tansey, Paleoclimatic inferences from an isotopic investigation of groundwater in the Central San Juan Basin, New Mexico, Quaternary Research, 26, 179-193, 1986.

Phillips, F.M., M.G. Zreda, L.V. Benson, M.A. Plummer, D. 
Elmore, and P. Sharma, Chronology for fluctuations in Late Pleistocene Sierra Nevada glaciers and lakes, Science, 274 (749-751), 1996.

Phillips, F.M., M.G. Zreda, J.C. Gosse, J. Klein, E.B. Evenson, R.D. Hall, O.A. Chadwick, and P. Sharma, Cosmogenic ${ }^{36} \mathrm{Cl}$ and ${ }^{10} \mathrm{Be}$ ages of Quaternary glacial and fluvial deposits of the Wind River Range, Wyoming, Geological Society of America Bulletin 109, 1453-1463, 1997.

Porter, S.C., K.L. Pierce, and T.D. Hamilton, Late Wisconsin mountain glaciation in the westem United States, in LateQuaternary Environments of the United States, edited by J. Wright, H. E., pp. 407, University of Minnesota Press, Minneapolis, 1983.

Porter, S.C., and A. Zhisheng, Correlation between climate events in the North Atlantic and China during the last glaciation, Nature, 375, 305-308, 1995.

Pyke, C.B., Some meteorological aspects of the seasonal distribution of precipitation in the Western United States and Baja, California, in University of California Water Resources Center Contribution, pp. 139, 1972.

Redmond, K.T., and R.W. Koch, Surface climate and streamflow variability in the western United States and their relationship to large-scale circulation indices, Water Resources Research, 27, 2381-2399, 1991.

Riehl, H., M.A. Alaka, C.L. Jordan, and R.J. Renard, The jet stream, Meteorology and Monograph, 2, 23-47, 1954.

Ropelewski, C.F., and M.S. Halpert, North American precipitation and temperature patterns associated with the El Nino/Southern Oscillation (ENSO), Monthly Weather Review, 114, 2352-2362, 1986.

Rose, T.P., M.L. Davisson, G.B. Hudson, and A.R. Varian, Environmental Isotope Investigation of Groundwater Flow in the Honey Lake Basin, California and Nevada, pp. 42, Lawrence Livermore National Laboratory, UCRL-ID127978, Livermore, CA, 1997.

Russell, I.C., Geological History of Lake Lahontan, a Quaternary lake of Northwestern Nevada, in U.S. Geological Survey Monograph 11, pp. 288, 1885.

Shackleton, N.J., The last interglacial in the marine and terrestrial records, Proceedings of the Royal Society of London, B174, 135-154, 1969.

Spaulding, W.G., Vegetation and climates of the last 45,000 years in the vicinity of the Nevada Test Site, south-central
Nevada, in U.S. Geological Survey Open-File Report 83535 , pp. 205, 1983.

Starrett, L.G., The relation of precipitation patterns in North America to certain types of jet streams at the 300-millibar level, Journal of Meteorology, 6, 347-352, 1949.

Stute, M., P. Schlosser, J.F. Clark, and W.S. Broecker, Paleotemperatures in the southwestern United States derived from noble gases in ground water, Science, 256, 1000-1003, 1992.

Syvitski, J.P., LeBlanc, K.W., and R.E. Cranston, The flux and preservation of organic carbon in Baffin Island fjord, in Glaciomarine Environments: Processes and Sediments, edited by J.A. Dowdeswell, and J.D. Scourse, pp. 217-239, Geological Society of London Special Publication 53, 1990.

Tang, M., and E.R. Reiter, Plateau Monsoons of the Northern Hemisphere: A comparison between North America and Tibet, Monthly Weather Review, 112, 617-637, 1984.

Taylor, K.C., G.W. Lamorey, G.A. Doyle, R.B. Alley, P.M. Grootes, P.A. Mayewski, J.W.C. White, and L.K. Barlow, The "flickering switch" of Late Pleistocene climate change, Nature, 361, 432-436, 1993.

Thompson, R, Global Holocene magnetostratigraphy, Hydrobiologia, 103, 45-51, 1983.

Thompson, R.S., L.V. Benson, and E.M. Hattori, A revised chronology for the last Pleistocene lake cycle in the central Lahontan basin, Quaternary Research, 25, 1-9, 1986.

Van Devender, T.R., Late Pleistocene Plants and Animals of the Sonoran Desert, a Survey of Ancient Packrat Middens in Southwestern Arizona, Doctorate thesis, University of Arizona, Tucson, 1973.

Wahrhaftig, C., and J.H. Birman, The Quaternary of the Pacific Mountain System in California. In Means of Correlation of Quaternary Successions, Vol. 8: Proceedings VII Congress International Association for Quaternary Research edited by R. Morrison, and H. E. Wright, pp. 293, 1956.

Welch, A.H., Ground-Water Quality and Geochemistry in Carson and Eagle Valleys, Western Nevada and Eastern California, in U.S. Geological Open-File Report 93-33, pp. 99, 1994.

Larry Benson, U.S. Geological Survey, 3215 Marine St., Boulder, CO 80303 